Article

\title{
Next-Generation Sequencing to Investigate Existing and New Insect Associations with Phytopathogenic Fungal Propagules
}

\author{
Émilie D. Tremblay ${ }^{1}$, Troy Kimoto ${ }^{2}$, Jean A. Bérubé ${ }^{3}$, and Guillaume J. Bilodeau 1,* \\ 1 Canadian Food Inspection Agency, 3851 Fallowfield Road, Nepean, Ont., K2H 8P9; \\ Emilie.Tremblay@canada.ca \\ 2 Canadian Food Inspection Agency, 4321 Still Creek Dr, Burnaby, BC, V5C 6S7; Troy.Kimoto@canada.ca \\ 3 Natural Resources Canada, Laurentian Forestry Centre, 1055 Du P.E.P.S. Street, P.O. Box 10380 Québec, QC, \\ G1V 4C7; Jean.Berube@canada.ca \\ * Correspondence: Guillaume.Bilodeau@canada.ca; Tel.: +1-343-212-0283
}

\begin{abstract}
Understanding ecological interactions is a key in managing phytopathology. Although entomologists rely mostly on both traditional molecular methods and morphological characteristics to identify pests, next-generation sequencing is becoming the go-to avenue for scientists studying fungal and oomycete phytopathogens. These organisms sometimes infect plants together with insects. There are many relationships yet to be discovered and much to learn about how these organisms interact with one another. Considering the growing number of exotic insect introductions in Canada, a high-throughput strategy for screening those insects is already implemented by the Canadian Food Inspection Agency (CFIA). However, no plan is deployed to investigate the phytopathogenic fungal and oomycete species interacting with insects. Metagenomics analysis was performed on the preservation fluids from CFIA's insect traps across Canada. Using the Ion Torrent PGM technology and fusion primers for multiplexing and indexing, community profiling was conducted on the different semiochemicals used in the insect traps and the various areas where these traps were placed. Internal transcribed spacer 1 (fungi and oomycetes) and adenosine triphosphate synthase subunit 9-nicotinamide adenine dinucleotide dehydrogenase subunit 9 spacer amplicons were generated. Although direct links between organisms could not be established, moderately phytopathogenic fungi (e.g., Leptographium spp. and Meria laricis) and oomycetes (mainly Peronospora spp. and Pythium spp.) unique to every type of semiochemical were discovered. The entomopathogenic yeast Candida michaelii was also detected. This project demonstrated our ability to screen for unwanted species faster and at a higher scale and throughput than traditional pathogen diagnostic techniques. Additionally, minimal modifications to this approach would allow it to be used in other phytopathology fields.
\end{abstract}

Keywords: Insects, Forest, Fungi, ITS1, metagenomics, NGS, Oomycete, Phytopathogens, Phytophthora, vectors 


\section{Introduction}

The Era of Globalization has dramatically and consistently increased international cargo shipments since 1970 [1]. Solid wood packaging material (SWPM) such as pallets, crates, and boxes are used to transport products all over the world. Bark and wood-boring insects, such as bark beetles, longhorned beetles, woodwasps, jewel beetles, weevils, and ambrosia beetles are often intercepted in SWPM [2-5]. Even with the implementation of International Standards for Phytosanitary Measures (e.g., ISPM No. 15), which states the need to treat wood products shipped abroad in order to prevent the spread of insects and diseases, live wood-boring insects are still intercepted in SWPM at Canadian and American borders [6,7]. Emerald ash borer (Agrilus planipennis), brown spruce longhorned beetle (Tetropium fuscum), sirex woodwasp (Sirex noctilio), and pine shoot beetle (Tomicus piniperda) are just a few examples of species recently introduced and established in Canadian forests [8-12].

The transmission of exotic phytopathogenic propagules, an important threat to forest health, figures among the many issues associated with the introduction of exotic insects in Canada, especially because some of these wood-boring insects proliferate within common North American tree species such as pine and spruce [13-16]. Aside from killing or damaging trees, insects can also transmit different phytopathogenic species (e.g., fungal spores) to their respective plant host. A noteworthy example is the fungus Ophiostoma ulmi, one of the causative agents of Dutch elm disease, transported to elm trees by bark beetles [15]. This fungus has devastated North American forests and also occurs in Asia and Europe [16,17]. Researchers have also previously reported potential links between insect and arthropod excreta and Phaeoacremonium spp. in grapevine infection cycle [18-20]. There are also numerous yeast associated with insects. More specifically, Candida spp. and Cladosporium spp. have been linked with bark and rove beetles [21-25]. Oomycetes contain numerous plant pathogens responsible for considerable damage to the environment as well [16,26-29]. Their propagative structures can remain viable for further plant infection even after ingestion and defecation by invertebrates [30]. For instance, chlamydospores of Phytophthora ramorum can still infect leaves after passing through the digestive tract of snails [30]. Oomycetes have also been associated with indirect interactions (positive or negative) with insects. For instance, while ants can transport P. palmivora and P. megakarya to cocoa trees, which can subsequently become infected [31], oviposition of the moth Spodoptera littoralis is enhanced after $P$. infestans modifies the volatile compounds emitted by the host plant [32]. In contrast, the reproductive output by aphids is inversely proportional to the level of Phytophthora infection [33-35].

Insects can also benefit from mutualistic relationships with plant pathogens that overwhelm the plant's defenses (e.g., thousand cankers disease), or induce a plant's cell suicide response [14,36,37]. Contrarily, the damage caused by insects can indirectly predispose plants to microbial attacks. For example, in addition to the maize crops losses caused by the African pink stem borer (Sesamia calamistis) and the false codling moth (Thaumatotibia leucotreta), it was observed that aflatoxin (produced by Aspergillus spp.) concentrations were proportional to the number of insects that came in contact with these crops after storage [38-40]. Many bark and ambrosia beetles even rely on a fungal symbiosis to fulfill their nutrition needs [41].

While there are numerous studies of insects transmitting plant viruses [42-44] and bacteria $[45,46]$, there is a need for additional research on associations between forest insects and microorganisms. Although there has been research on pinewood nematode [37,47], ophiostomatoid fungi $[14,15,31,48]$, and their insect vectors, there are likely more associations to be discovered, including transmission by vectors. For instance, additional fungal species never previously found to be associated with insect species may also be unexpectedly transmitted in this way.

The Canadian Food Inspection Agency (CFIA) conducts annual surveys using traps baited with semiochemicals to detect nonnative wood-boring insects in high-risk areas such as industrial and commercial zones [49-52]. Semiochemicals are communication chemicals to induce inter- or intraspecific interactions between organisms (e.g., decaying trees produce a kairomone that attracts bark beetles) [53]. They have been extensively studied for their ability to attract specific insects [47,54-60], especially for monitoring particular groups of beetles and the microorganisms associated 
with them. With the advances associated with next-generation sequencing (NGS), scientists have used the power of metagenomics for the diagnosis of phytoviruses [42], fungi, and oomycetes [61], and the detection of exotic fungi on asymptomatic live plant material imported into Canada [62]. In addition to its high-throughput sequencing capacity and high sensitivity, NGS also allows for the analysis of hundreds of environmental samples in a fraction of the time compared with traditional methods [63-65].

Taking advantage of a well-established, nationwide entomological survey that uses preservation fluids within insect traps, this project aimed to use a metagenomics approach to screen for the presence of potentially phytopathogenic oomycetes and fungi in order to fill in a gap in plant pathogens detection. The approach could potentially help forest pathology stakeholders to orientate surveys for disease monitoring and management at a large scale. In attempting to partially decipher complex tree infection processes (e.g., insect-fungi) by extracting additional and valuable information from the insect trap samples, the project also addressed the potential for wood-boring insects to actively, or incidentally carry phytopathogenic propagules into baited insect traps. Evaluation of commonalities between the areas of collection or the specific semiochemicals used and the respective fungal or oomycete diversity was also conducted.

\section{Materials and Methods}

Insect traps: During the summers of 2013 to 2015, CFIA inspectors installed traps at 41 sites in industrial and commercial zones, landfills, and SWPM disposal facilities (Supplementary Figure S1). These areas are end points for international SWPM and dunnage, and are considered high-risk areas for the introduction of nonnative pests. At each site, 12-unit funnel traps with wet collection cups (Synergy Semiochemicals Corporation, Burnaby, BC, Canada) were suspended between trees. Each trap's collection cup was positioned at approximately 30 to $200 \mathrm{~cm}$ above ground, according to the height of the understory vegetation. Depending on local temperatures, baited traps were placed in forested areas between March and April, and taken down at the end of September. To assess the fungal communities (background noise) in the sampled areas, non-baited air samples were collected using Johnson and Barnes (JB) rainfall collectors (J. L. Johnson, personal communication) as previously done by Barnes et al., Szabo et al. and Hambleton et al. [66-69]. Because un-baited 12-unit trap could not be used within an operational program, these JB air samplers were employed as negative controls.

Semiochemicals: In 2013 and 2014, CFIA inspectors placed six traps per site. Half the traps were baited with one combination of lures, while the other half was baited with a different set. Inspectors attached one lure type to each trap with each lure dispensed from individual release devices. Additional details pertaining to the semiochemicals (chemical composition, purity, packaging, and release rate) used in this project are provided in Supplementary Material S1.

The first semiochemical combination $\left(\mathrm{C}_{6} \mathrm{C}_{8}\right)$ contained ethanol, as well as aggregation pheromones of some longhorned beetles in the Cerambycinae subfamily [54]. The second semiochemical combination (UHR_E_AP) contained ethanol and alpha-pinene, which are attractive to a wide range of bark and wood-boring insects $[49,55,56]$. Traps baited with $C_{6} C_{8}$ were suspended between coniferous or broadleaf trees, whereas traps containing UHR_E_AP were primarily placed between coniferous trees.

In 2015, CFIA inspectors implemented two new semiochemical sets in order to target different insect taxa. The first semiochemical (i.e., General Longhorn) was attractive to longhorned beetles in the Spondylidinae [57] and Lamiinae subfamilies [70] but, could also capture various bark and ambrosia beetles, due to the addition of ethanol [58]. The second semiochemical set (Pine Sawyer) was attractive to Monochamus (longhorned beetles) species from North America, Europe, and Asia $[47,59,60]$ but the inclusion of ethanol and alpha-pinene also makes it attractive to bark and ambrosia beetles.

The semiochemical sets were deployed in different areas depending on the forest type. In British Columbia, each site had four traps baited with the Pine Sawyer lures, and two traps baited with the General Longhorn. In Ontario and Quebec, $75 \%$ of the sites were in broadleaf forests or 
mixed forests, and all six traps were baited with General Longhorn lure. The remaining sites, composed primarily of coniferous trees, were baited with the Pine Sawyer lure. In the Atlantic provinces (i.e., New Brunswick, Newfoundland and Labrador, Nova Scotia, and Prince Edward Island), each site had three traps with Pine Sawyer lure and three traps with General Longhorn lure. Traps baited with the Pine Sawyer lure were suspended between two coniferous trees, whereas traps baited with the General Longhorn lure were placed between coniferous or broadleaf trees. Collected fluids from each trap (i.e., insect traps and air samplers) were kept and analyzed separately. Lures were replaced approximately every 90 days.

Trapping fluid (200 to $300 \mathrm{~mL}$ of USP/FCC grade 1,2-propanediol (propylene glycol) (Fisher Scientific, Hampton, NH, USA), (Denatonium benzoate or Bitrex ${ }^{\circledR}=$ [Benzyl-diethyl (2,6-xylylcarbamoyl methyl) ammonium benzoate]) (Sigma-Aldrich, Saint-Louis, Mo., USA), and PhotoFlo 200 (surfactant) (Fisher Scientific) were poured into the collection cups of each trap, and traps were spaced at least $25 \mathrm{~m}$ from each other [71,72]. All of the solution from each trap was collected every two to three weeks. The contents were poured onto fine-gauged sieves and insects were removed because only the collection fluid was analysed in this study. The liquids were then filtered on $0.45-\mu \mathrm{m}$ cellulose paper filters and stored at $4^{\circ} \mathrm{C}$ until processed. The filter papers were cut in half to preserve a section as a back-up, while the other half was put in Tris buffer, heated at $65^{\circ} \mathrm{C}$ and sonicated $(40 \mathrm{kHz})$. The solution containing the DNA was then centrifuged $(10,000 \mathrm{rpm}, 2$ min) and extracted with the FastDNA kit for soil (MP Biomedicals, Santa Ana, CA, USA). To remove PCR inhibitors, purification of the extracted DNA was done using magnetic particles (Bio-Nobile, Östernäsvägen, Finland).

Then, PCR was performed bidirectionally to amplify DNA and add unique identifier (barcodes) to each sample using Ion Torrent PGM fusion primers. Detailed sequences for fungi and oomycete fusion primers, as well as PCR cycling and parameters can be found in Tremblay et al. [61]. Fusion primers allowed for multiplexing environmental samples and generating internal transcribed spacer 1 (ITS1) fungi and oomycete amplicons. In addition, when an oomycete band was visualized by electrophoresis, another PCR targeting the adenosine triphosphate synthase subunit 9-nicotinamide adenine dinucleotide dehydrogenase subunit 9 (ATP9-NAD9) spacer was performed to allow for the proper downstream resolution of Phytophthora species, considering that it is better-suited than the ITS to resolve species within this genus [29,73-75]. Products were visualized on a $1.5 \%$ agarose gel with a Gel Doc XR+ Gel Documentation System (Bio-Rad Laboratories, Inc., Hercules, CA, USA). Primer-dimers and other smaller sized fragments $(<100 \mathrm{bp})$ were removed with Agencourt AMPure XP magnetic beads at a 0.7:1 beads:DNA ratio (Agencourt Bioscience, Beverly, MA, USA) [76]. Sequencing libraries were quantified with the Ion Universal Library Quantitation qPCR Kit, (Life Technologies, Carlsbad, CA, USA), and then pooled at the equimolar concentration of $16 \mathrm{pM}$. The Ion Personal Genome Machine (PGM) Template OT2 Kit $400 \mathrm{bp}$ (Life Technologies) and the Ion PGM sequencer (Life Technologies) were used to perform NGS [77].

Bioinformatics: The raw data output from the sequencer was analysed with the pipeline previously described by Tremblay et al. [61]. FASTQ files were converted into sequence (FASTA) and quality score (QUAL) files using fastqutils [78]. Quality trimming based on sequence quality and length was done with Mothur (version 1.37.2) [79] using the trim.seqs function parameters minlength $=120$, maxambig $=0$, and maxhomop $=8$. ITS extraction was done with ITSx (version 1.0.11) [80]. Operational taxonomic unit (OTU) tables were generated with QIIME (version 1.7.0) [81]. Taxonomic assignment was done using the UNITE database (version 31.01.2016) [82] for fungi and the National Center for Biotechnology Information (NCBI) nucleotide database for oomycetes. The resolution power of the ATP9-NAD9 region for Phytophthora species relies on a custom-built database including the majority of all currently described Phytophthora species (NCBI accessions numbers JF771616.1 to JF772053.1 and JQ439009.1 to JQ439486.1) [29,83]. To evaluate species alpha diversity, evenness, and the proportion of different organisms within the sample types, statistical analyses were done with $\mathrm{R}$ (version 3.1.3) [84] using the RAM package (version 1.2.1.3) [85]. This package was also used to evaluate common elements between dataset (Venn diagrams), to assess similarities through Principal Coordinates Analysis (PCoA) plots, and to generate sampling maps. 
To visualize the distribution of the type of trees that were used to hang traps at the collection sites, a data aggregation plot was built using UpsetR version 1.3.3 [86] in R.

Species subtraction. Species subtraction hereafter refers to the dataset excluding species that were commonly detected in both the control and insect traps. Insect trapping procedures were already established by the CFIA biologists and sites were selected by CFIA inspectors prior to this project [87]. Although CFIA entomologists screened and identified all wood-boring insects, due to time constraints, they only reported the non-indigenous insects captured during the survey. Considering the physical design of the insect traps, the passive collection of fungal spores suspended in air was inevitable. In an attempt to extract unique features associated with insects attracted to the different types of semiochemicals, NGS data from JB collector air samples, collected in similar context as insect traps (i.e., same areas, sampling time, sites, year, season, and so on), was used to identify which fungal OTU were solely found in insect traps. Although the JB collectors were passive spore samplers, through species subtraction it was possible to determine which fungi or oomycetes species were unique to the insect traps and may be associated with an insect vector.

Following BLAST alignments of the OTU with the respective reference databases, the remaining species were screened against a text-formatted database to determine their fungal biological functions [88], and the resulting file was parsed to identify fungi of interest, mostly those known to be plant pathogens and rot fungi. Ectomycorrhizal fungi, saprotrophs, mycoparasites, lichenized fungi, and most yeast were discarded.

To assess the depth of sequencing and diversity of the subtracted and negative control data (i.e., spore trap), and to compare them with the original insect trap data, rarefaction curves were generated using the functions "diversity" and "rarefy" from the R package Vegan (version 2.5-2) [89]. This step was performed only on fungal data as the oomycete dataset was too small to obtain relevant rarefaction curves.

\section{Results}

Samples. A total of 108 samples originating from British Columbia, New Brunswick, Newfoundland and Labrador, Nova Scotia, Ontario, Prince Edward Island and Quebec were collected over three years (2013 to 2015). From those samples, 39 were baited with UHR_E_AP, 36 with $\mathrm{C}_{6} \mathrm{C}_{8}, 17$ with General Longhorn, and 16 with Pine Sawyer (Supplementary Table S1). As well, Figure 1 presents the type of trees to which sample traps were hung for sampling. However, the data does not fully represent the type of forest surrounding sampling sites because traps were only suspended from two trees.

PCRs. Fungal amplicons (ITS1) generated a visible band via gel electrophoresis in $\geq 83 \%$ of samples, whereas oomycete amplicons (ITS1) were observed in only $11 \%$ of samples (Table 1). Forty percent of oomycete amplicons generated bands for Phytophthora spp. following the PCR amplification of the ATP9-NAD9 spacer (Table 1).

Fungal OTU, prior to species subtraction. At the phylum level, the most abundant fungi for all semiochemical treatments were members of the Ascomycota division, followed by Basidiomycota, unidentified OTU, OTU "unclassified below kingdom", Chytridiomycota, Zygomycota, and then Glomeromycota (Table 2). A few Rozellomycota members were associated with all lures except for General Longhorn (Table 2). Ascomycetes and basidiomycetes were evenly distributed between the samples baited with UHR_E_AP and $\mathrm{C}_{6} \mathrm{C}_{8}$ semiochemicals but, there were larger proportions of ascomycetes compared with the proportion of basidiomycetes found in the General Longhorn and Pine Sawyer-baited samples (Table 2). At the genus level, the most abundant fungal OTU remained unidentified regardless of the semiochemical analysed but, Phoma sp., Leptographium sp., and Mycosphaerella sp., while below $5 \%$ in proportion, are genera that include many forest pathogens (Table 3). The UHR_E_AP and $\mathrm{C}_{6} \mathrm{C}_{8}$ semiochemicals contained higher percentages of Rhodotorula sp. and Cystobasidium sp. compared with the General Longhorn and Pine Sawyer semiochemicals, which only contained traces of these genera. Instead, the two latter semiochemicals had more Cryptococcus sp. and Leptographium sp. All four semiochemicals had low amounts of Epicoccum sp. 
Analysis of the top ten species in relation to lure type revealed a high number of "unidentified fungal OTU" and "OTU unclassified below genus" in all four attractants (Table 4). Other species, including Rhodotorula mucilaginosa, Cystobasidium slooffiae, Leptographium piriforme, Cladosporium exasperatum, and Aureobasidium pullulans were frequent across the different semiochemical treatments (Table 4).

From the 2439 different species OTU detected prior to the species subtraction, 1057 (43\%) were common to all semiochemical types, 228 species $(9 \%)$ were unique to the UHR_E_AP semiochemical, $112(4.6 \%)$ were unique to General Longhorn, $105(4.3 \%)$ were unique to Pine Sawyer, and $118(4.8 \%)$ were unique to the $\mathrm{C}_{6} \mathrm{C}_{8}$ semiochemical (Figure 2a).

To visualize sampling depth, examples of the rarefaction curves obtained for the spore traps (negative control) and their respective original insect dataset, and subtracted insect dataset are shown in Supplementary Figure S2. The spore trap data demonstrated the highest sequencing depth as saturation was obtained for all of the samples tested with a sequence number per sample ranging between approximately 5,000 and 25,000. The lowest species number obtained by all samples tested was just below 150. In contrast, only part of the samples from both the original insect and the subtracted data reached saturation in their respective rarefaction curves.

Fungal OTU, after species subtraction. A total of 1,527 species remained once the species detected in the negative control were discarded, of which 368 species (approximately 25\%) were common to all semiochemical types, 220 species (approximately 14\%) were unique to UHR_E_AP, $109(7.1 \%)$ were unique to General Longhorn, 99 (6.5\%) were unique to Pine Sawyer, and $116(7.6 \%)$ were unique to the $\mathrm{C}_{6} \mathrm{C}_{8}$ lure (Figure $2 \mathrm{~b}$ ). Following the approach of Tedersoo et al. [88] to investigate fungal species functions, the data revealed the occurrence of some species of moderate concern in each of the semiochemical treatments (Supplementary Table S2). In Pine Sawyer-baited samples, three rot fungi and six phytopathogenic fungi (including Ambrosiella ferruginea, Leptographium sp., and Phaeoacremonium inflatipes) were detected. From the General Longhorn samples, five rot fungi and eight phytopathogenic causal agents, including Echinodontium tinctorium, Siroccocus conigenus, and Pucciniastrum circaeae were detected. The $\mathrm{C}_{6} \mathrm{C}_{8}$ semiochemical treatment featured unique fungi of interest as well: a single white rot, the yeast Candida michaelii, which is associated with the gut flora of handsome fungus beetles (Endomychidae), and eight phytopathogens including Phyllosticta minima, Podosphaera clandestina, and Ciborinia Whetzelii. Finally, the UHR_E_AP semiochemical had six rots along with thirteen pathogenic fungi including Colletotrichum fructi, Podosphaera leucotricha, and Strelitziana mali.

Oomycetes OTU, prior to species subtraction. At the phylum level, BLAST alignments of the OTU sequences with the ones in the NCBI (nucleotides) database showed that OTU from ITS1 amplicons using oomycete primers predominantly aligned with Oomycota sequences. However, the UHR_E_AP (26.1\%) and $\mathrm{C}_{6} \mathrm{C}_{8}(26.6 \%)$ semiochemicals had moderate percentages of OTU which could not be identified below the kingdom taxonomic rank (Table 5). On the other hand, the majority of sample sequences from traps baited with General Longhorn (99.9\%) and Pine Sawyer (96.9\%) corresponded to Oomycota members (Table 5). Among all genera detected that could be identified, Peronospora spp. was the most abundant in all semiochemical treatments, except for $\mathrm{C}_{6} \mathrm{C}_{8}$, where Phytophthora spp. was the most abundant identified genus (Table 5). Prior to species subtraction, of the total 54 different OTU, there were 21 species detected in all semiochemical types but, few were unique to each treatment (Figure 2c). Pythium monospermum was unique to traps baited with the UHR_E_AP semiochemical. Pythium oligandrum was unique to traps baited with the Pine Sawyer semiochemical. Five species were unique to traps baited with the General Longhorn semiochemical (Peronospora sp. UPS F-119986, P. flava, P. sparsa, Pythium carolinianum, and Phytophthora spp.). No unique species were recovered from traps baited with the $\mathrm{C}_{6} \mathrm{C}_{8}$ semiochemical (Figure 2c). Within the top ten most abundant species identified, all semiochemicals except $\mathrm{C}_{6} \mathrm{C}_{8}(0.67 \%)$ had a high percentage of Peronospora manshurica (Table 6). The UHR_E_AP (26.1\%) and $\mathrm{C}_{6} \mathrm{C}_{8}(26.6 \%)$ semiochemicals had a considerably higher number of OTU unclassified below genus compared with General Longhorn (traces) and Pine Sawyer (3.02\%). 
Oomycetes OTU, after species subtraction. Following species subtraction, fifteen species remained, from which no unique oomycete species were detected in either the Pine Sawyer or UHR_E_AP baited traps (Figure 2d). Eleven species were unique to General Longhorn including Peronospora sp., one was unique to $\mathrm{C}_{6} \mathrm{C}_{8}$ (Pythium sp. CAL-2011e), and three species were shared with the two latter semiochemicals (Supplementary Table S3).

Phytophthora spp. OTU, prior to species subtraction: No Phytophthora sp. were unique to the insect traps, or any semiochemical treatment. Additionally, ATP9-NAD9 OTU from the original dataset generated prior to the species subtraction could only recover Phytophthora spp. from traps baited with the $\mathrm{C}_{6} \mathrm{C}_{8}$ and UHR_E_AP semiochemicals. Phytophthora cryptogea could only be detected from traps baited with the UHR_E_AP semiochemical, whereas P. foliorum, Phytophthora sp. "kelmania" [83] and P. syringae were associated with both $\mathrm{C}_{6} \mathrm{C}_{8}$ and UHR_E_AP lures.

Diversity: fungi. The fungal species evenness (Shannon index [90]) was very similar between all four semiochemicals, with median relative values ranging between 0.5 and 0.75 (Supplementary Figure S3a). The true diversity median values for fungi (Shannon index, per unit of number of species [90,91]) were also evenly distributed among all semiochemical types, ranging between approximately 20 and 40 units of number of species (Supplementary Figure S3b).

Diversity: oomycetes. Oomycete species evenness (Shannon index) revealed a notable variation between the different semiochemicals (Supplementary Figure S3c). While species from the $\mathrm{C}_{6} \mathrm{C}_{8}$ (median relative value of approximately 0.45) and the UHR_E_AP (median relative value of approximately 0.49) lures were evenly distributed, species from Pine Sawyer (median relative value of approximately 0.15) and the General Longhorn-baited traps (median relative value of approximately 0.2) were much less evenly distributed. These differences help explain the true diversity (Shannon) variation also observed in Supplementary Figure S3d.

Areas of collection. After discarding fungal and oomycete species that were most likely passively, or incidentally captured in the insect traps, we observed certain community aggregations associated with geographic regions. The sampling sites were split in three areas of Canada: West Coast (i.e., British Columbia), Eastern Canada (i.e., Quebec and Ontario) and the Atlantic Region (i.e., New Brunswick, Newfoundland and Labrador, Nova Scotia, and Prince Edward Island). The PCoA plot generated at the order level for fungi (Supplementary Figure S4a) demonstrated a clear similarity (i.e., clustering) between OTU data from the West Coast, a clustering trend for Eastern Canada data, and a lack of similarity within the Atlantic Region. At the class level, however, the OTU clustered more clearly based on the geographic region (Supplementary Figure S4b). Such observation was not possible for oomycetes because not enough species remained following the species subtraction (data not shown). Although, there were oomycete species unique to the Eastern zone, and aside from Saprolegnia sp. SAP1 and Hyaloperonospora cochleariae, all others were either Peronospora spp. (P. farinosa, P. sparsa, Peronospora sp. UPS F-119986, P. viciae, and Peronospora sp. isolate 079405,59), or Pythium species (Pythium aff. hypogynum, Pythium sp. CAL-2011f, Pythium sp. AvdB-2012, Pythium sp. P19300/1/3, and Pythium sp. BP2013k). One species-Pythium sp. BG02was unique to the West Coast data but, there were no species uniquely associated with the Atlantic Region. 
3.1. Figures, Tables and Schemes

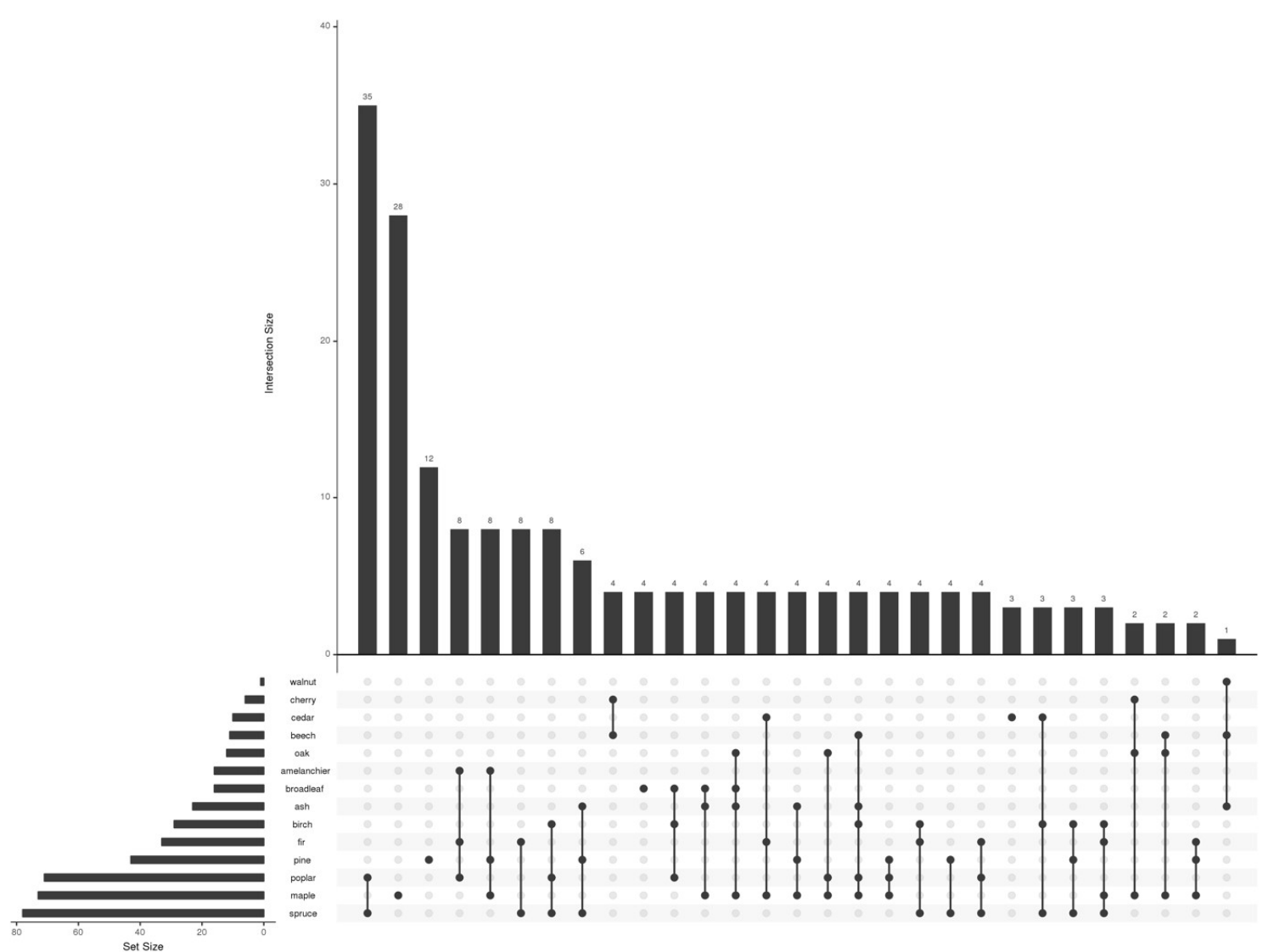

Figure 1. Upset plot to visualize the type of trees from which traps were suspended. The intersection size number represents the number of times a specific tree combination was found (similar to a Venn diagram), and the set size number corresponds to the number of samples surrounded by a specific type of tree. Most samples were collected from traps placed in forested areas comprising more than one tree species. 

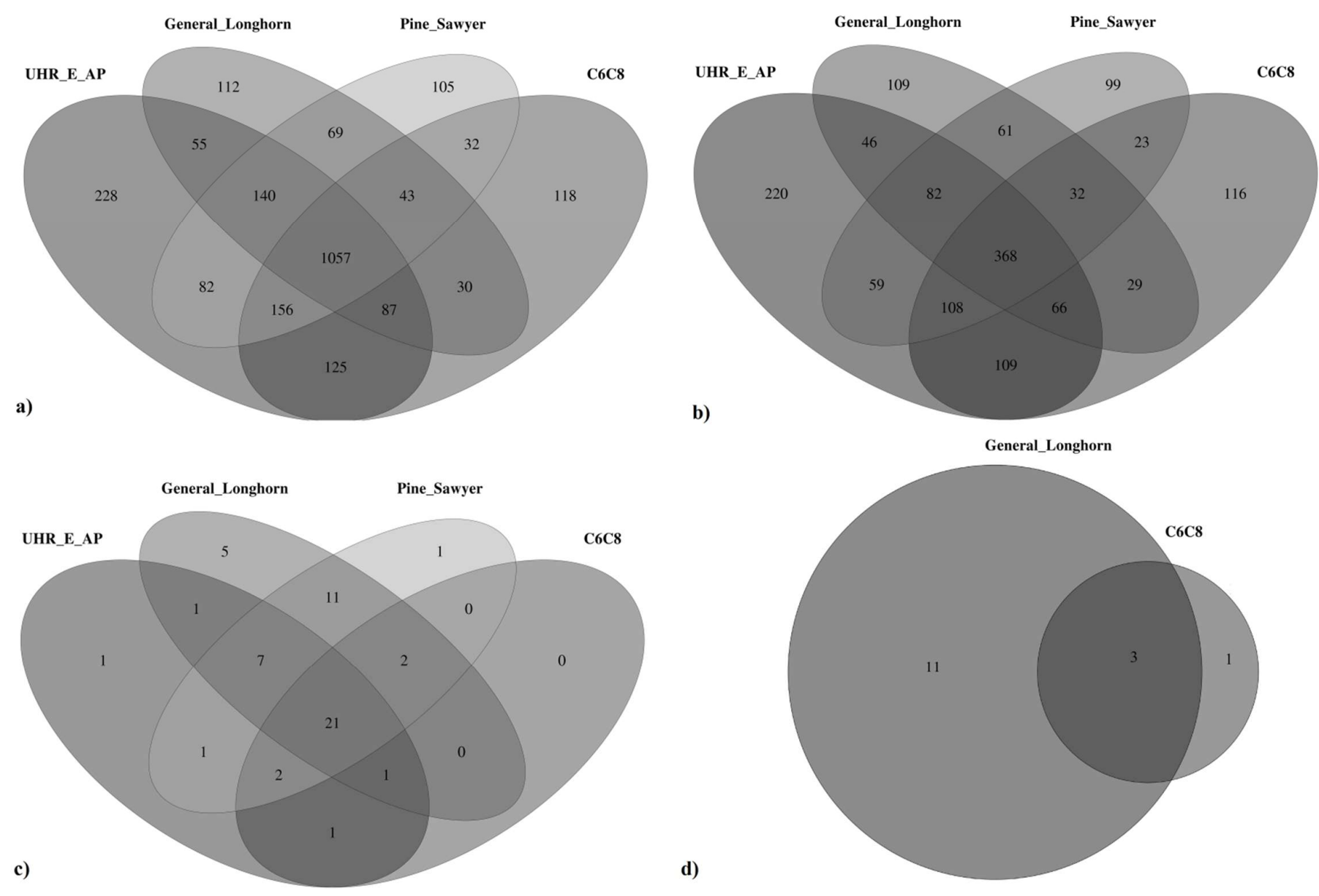

d)

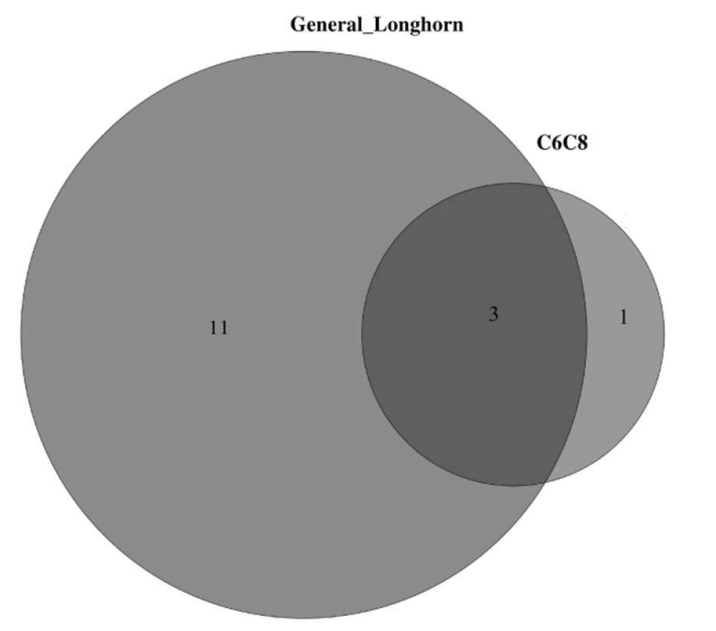

Figure 2: Venn diagram of a) fungal species shared or unique to the semiochemical type employed in insect traps, b) fungal species shared or unique to the semiochemical type employed in insect traps after species subtraction, c) oomycete species shared or unique to the semiochemical type employed in insect traps, d) oomycete species shared or unique to the semiochemical type employed in insect traps after species subtraction. All were obtained by amplifying the ITS1 genic region. 
Table 1: Presence or absence of amplification as detected by gel electrophoreses using barcoded PCR products from 108 environmental insect samples by targeted organisms, and the percentages of positive reactions obtained.

\begin{tabular}{|c|c|c|c|c|c|}
\hline $\begin{array}{l}\text { Primer used to append } \\
\text { barcodes }^{\mathrm{a}}\end{array}$ & Organism & $\begin{array}{l}\text { Target } \\
\text { region }\end{array}$ & $\begin{array}{l}\text { Positive } \\
\text { PCR }\end{array}$ & $\begin{array}{l}\text { Total } \\
\text { PCR }\end{array}$ & Positive $(\%)^{c}$ \\
\hline ITS1-Forward & Fungi & \multirow{4}{*}{ ITS1 } & 90 & 108 & 84 \\
\hline ITS1-Reverse & Fungi & & 98 & 108 & 91 \\
\hline ITS1-Forward & Oomycete & & 12 & 108 & 11 \\
\hline ITS1-Reverse & Oomycete & & 12 & 108 & 11 \\
\hline ATP9-NAD9- forward & Phytophthora sp. & ATP9-NAD9 & 8 & 20 & 40 \\
\hline Total & $\ldots$ & $\ldots$ & 220 & 452 & Average: 47 \\
\hline
\end{tabular}

Table 2: Operational Taxonomic Units: fungal identification proportion (\%) by semiochemical type at the Phylum taxonomic level using the ITS1 genic region.

\begin{tabular}{lcccc}
\hline \multicolumn{1}{c}{ Semiochemical $^{\mathbf{a}}$} & UHR_E_AP & ${\text { C } 6 \mathbf{C}_{8}}$ & General Longhorn & Pine Sawyer \\
\hline Phylum & & & & \\
Ascomycota & 39.6 & 41.6 & 63.9 & 68.5 \\
Basidiomycota & 39.5 & 40.9 & 24.2 & 23.0 \\
Unidentified OTU & 17.5 & 14.2 & 9.3 & 5.6 \\
OTU unclassified & & & & 2.4 \\
below kingdom & 3.1 & 3.1 & 2.4 & 0.2 \\
Chytridiomycota & 0.3 & 0.1 & 0.1 & 0.2 \\
Zygomycota & 0.1 & 0.1 & 0.1 & traces \\
Glomeromycota & traces & 1.0 & traces & traces \\
Rozellomycota & traces & 0.5 & absent & \\
\hline
\end{tabular}

aUHR_E_AP = Ultra-high release ethanol and ultra-high release alpha-pinene.

$\mathrm{C}_{6} \mathrm{C}_{8}=$ Racemic 3-hydroxyhexan-2-one (K6), racemic 3-hydroxyoctan-2-one (K8), and ultra-high release ethanol.

General Longhorn = Ultra-high release ethanol, $(E)-6,10$-dimethyl-5,9-undecadien-2-ol (E-fuscumol), and (E)-6,10-dimethyl-5,9-undecadien-2-yl (E-fuscumol acetate).

Pine Sawyer $=$ 2-undecyloxy-1-ethanol (monochamol), ultra-high release ethanol, ultra-high release alpha-pinene, and racemic 2-methyl-6-methylene-7-octen-4-ol (ipsenol).

bBelow $0.01 \%$ or not in the top 10 for this semiochemical. 
Table 3: Operational Taxonomic Units: fungal identification proportion (\%) by semiochemical type at the genus taxonomic level using the ITS1 genic region.

\begin{tabular}{|c|c|c|c|c|}
\hline Semiochemical $^{a}$ & UHR_E_AP & $\mathrm{C}_{6} \mathrm{C}_{8}$ & General Longhorn & Pine Sawyer \\
\hline \multicolumn{5}{|l|}{ Genus } \\
\hline Unidentified OTU & 40.5 & 34.2 & 29.5 & 30.0 \\
\hline Rhodotorula & 10.0 & 11.0 & tracesb & 3.2 \\
\hline Cystobasidium & 7.5 & 5.5 & traces & traces \\
\hline Cryptococcus & 4.3 & 4.1 & 5.5 & 6.1 \\
\hline OTU unclassified below family & 3.1 & 3.1 & 2.4 & 2.4 \\
\hline Alternaria & 2.9 & traces & traces & traces \\
\hline Epicoccum & 2.5 & 5.2 & 3.3 & 2.2 \\
\hline Phoma & 2.2 & 3.2 & traces & traces \\
\hline Scopuloides & 1.8 & traces & traces & traces \\
\hline Verticillium & 1.8 & 2.2 & traces & traces \\
\hline Hannaella & traces & 2.3 & traces & traces \\
\hline Wickerhamomyces & traces & 1.8 & traces & traces \\
\hline Aureobasidium & traces & traces & 5.3 & traces \\
\hline Leptographium & traces & traces & 5.2 & 4.4 \\
\hline Cladosporium & traces & traces & 3.9 & 7.3 \\
\hline Neurospora & traces & traces & 3.2 & traces \\
\hline Kluyveromyces & absent & traces & 3.0 & traces \\
\hline Torulaspora & traces & traces & 2.3 & traces \\
\hline Candida & traces & traces & traces & 8.0 \\
\hline Mycosphaerella & traces & traces & traces & 3.1 \\
\hline Geopyxis & traces & traces & traces & 2.0 \\
\hline
\end{tabular}

aUHR_E_AP = Ultra-high release ethanol and ultra-high release alpha-pinene.

$\mathrm{C}_{6} \mathrm{C}_{8}=$ Racemic 3-hydroxyhexan-2-one (K6), racemic 3-hydroxyoctan-2-one (K8), and ultra-high release ethanol.

General Longhorn = Ultra-high release ethanol, (E)-6,10-dimethyl-5,9-undecadien-2-ol (E-fuscumol), and (E)-6,10-dimethyl-5,9-undecadien-2-yl ( $E$-fuscumol acetate).

Pine Sawyer = 2-undecyloxy-1-ethanol (monochamol), ultra-high release ethanol, ultra-high release alpha-pinene, and racemic 2-methyl-6-methylene-7-octen-4-ol (ipsenol).

bBelow $0.01 \%$ or not in the top 10 for this semiochemical. 
Table 4: Operational Taxonomic Units: fungal identification proportion (\%) by semiochemical type at the species taxonomic level (top 10 species) using the ITS1 genic region.

\begin{tabular}{lcccc}
\hline \multicolumn{1}{c}{ Semiochemical $^{\text {a }}$} & UHR_E_AP & $\mathbf{C}_{6} \mathbf{C}_{8}$ & General Longhorn & Pine Sawyer \\
\hline Species & & & & \\
fungi sp. & 17.5 & 14.2 & 9.3 & 5.6 \\
Rhodotorula mucilaginosa & 8.2 & 8.5 & traces $^{\mathrm{b}}$ & 2.7 \\
Cystobasidium slooffiae & 6.4 & 3.3 & traces & traces \\
Ascomycota sp. & 5.3 & 4.5 & 2.8 & 5.9 \\
OTU unclassified below genus & 9.6 & 3.1 & 2.4 & 2.4 \\
Epicoccum nigrum & 2.5 & 5.2 & 3.3 & 2.2 \\
Alternaria alternata & 2.5 & traces & traces & traces \\
Scopuloides hydnoides & 1.8 & traces & traces & traces \\
Verticillium dahliae & 1.8 & 2.2 & traces & traces \\
Cystobasidium pinicola & traces & 2.2 & traces & traces \\
Hannaella luteola & traces & 1.9 & traces & traces \\
Wickerhamomyces anomalus & traces & 1.8 & traces & traces \\
Leptographium piriforme & traces & traces & 5.2 & 4.4 \\
Aureobasidium pullulans & traces & traces & 5.1 & traces \\
Cladosporium exasperatum & traces & traces & 3.9 & 6.9 \\
Neurospora terricola & traces & traces & 3.2 & traces \\
Kluyveromyces wickerhamii & absent & absent & 2.9 & traces \\
Torulaspora delbrueckii & absent & traces & 2.3 & traces \\
Candida sp. & traces & traces & traces & 7.9 \\
Mycosphaerellaceae sp. & traces & traces & traces & 3.0 \\
\hline In_EP = & & & & \\
\hline
\end{tabular}

aUHR_E_AP = Ultra-high release ethanol and ultra-high release alpha-pinene.

$\mathrm{C}_{6} \mathrm{C}_{8}=$ Racemic 3-hydroxyhexan-2-one (K6), racemic 3-hydroxyoctan-2-one (K8), and ultra-high release ethanol. General Longhorn = Ultra-high release ethanol, $(E)-6,10$-dimethyl-5,9-undecadien-2-ol (E-fuscumol), and (E)-6,10-dimethyl-5,9-undecadien-2-yl (E-fuscumol acetate).

Pine Sawyer $=$ 2-undecyloxy-1-ethanol (monochamol), ultra-high release ethanol, ultra-high release alpha-pinene, and racemic 2-methyl-6-methylene-7-octen-4-ol (ipsenol).

bBelow $0.01 \%$ or not in the top 10 for this semiochemical. 
5 of 43

Table 5: Operational taxonomic units: oomycete identification proportion (\%) by semiochemical type at the Phylum and Genus taxonomic levels using the ITS1 genic region.

\begin{tabular}{|c|c|c|c|c|}
\hline Semiochemicala $^{a}$ & UHR_E_AP & $\mathrm{C}_{6} \mathrm{C}_{8}$ & General Longhorn & Pine Sawyer \\
\hline \multicolumn{5}{|l|}{ Phylum } \\
\hline Oomycota & 73.9 & 73.4 & 99.9 & 96.9 \\
\hline OTU unclassified below & & & & \\
\hline kingdom & 26.1 & 26.6 & 0.01 & 3.02 \\
\hline \multicolumn{5}{|l|}{ Genus } \\
\hline Peronospora & 38.7 & 8.55 & 64.1 & 9.39 \\
\hline OTU unclassified below family & 26.1 & 26.6 & 0.01 & 0.30 \\
\hline Phytophthora & 18.4 & 46.5 & 16.3 & absent \\
\hline Pythium & 13.1 & 14.4 & 17.5 & 0.14 \\
\hline Hyaloperonospora & 1.90 & 2.68 & 0.87 & 0.15 \\
\hline Plasmopara & 1.72 & absent & 0.13 & absent \\
\hline Basidiophora & 0.13 & 1.34 & 1.07 & 0.01 \\
\hline Saprolegnia & absent & absent & traces ${ }^{b}$ & traces \\
\hline
\end{tabular}

aUHR_E_AP = Ultra-high release ethanol and ultra-high release alpha-pinene.

$\mathbf{C}_{6} \mathbf{C}_{8}=$ Racemic 3-hydroxyhexan-2-one (K6), racemic 3-hydroxyoctan-2-one (K8), and ultra-high release ethanol.

General Longhorn = Ultra-high release ethanol, $(E)$-6,10-dimethyl-5,9-undecadien-2-ol (E-fuscumol), and

(E)-6,10-dimethyl-5,9-undecadien-2-yl (E-fuscumol acetate).

Pine Sawyer $=2$-undecyloxy-1-ethanol (monochamol), ultra-high release ethanol, ultra-high release alpha-pinene, and racemic

2-methyl-6-methylene-7-octen-4-ol (ipsenol).

bBelow $0.01 \%$ or not in the top 10 for this semiochemical. 
6 of 43

Table 6: Operational Taxonomic Units: oomycete identification proportion (\%) by semiochemical type at the species taxonomic level (top 10 species) using the ITS1 genic region.

\begin{tabular}{lcccc}
\hline \multicolumn{1}{c}{ Semiochemical } & UHR_E_AP & $\mathbf{C}_{6} \mathbf{C}_{8}$ & General Longhorn & Pine Sawyer \\
\hline Species & & & & \\
Peronospora manshurica & 26.7 & 0.67 & 61.3 & 84.9 \\
OTU unclassified below genus & 26.1 & 26.6 & traces $^{\mathrm{b}}$ & 3.02 \\
Phytophthora sp. & 18.04 & 46.2 & 16.3 & traces \\
Peronospora aestivalis & 8.20 & 2.82 & 1.36 & 1.47 \\
Pythium sp. CAL-2011e & 4.61 & 11.4 & $\mathrm{NA}$ & $\mathrm{NA}$ \\
Pythium hypogynum & 4.14 & 1.63 & traces & traces \\
Peronospora alta & 2.11 & 4.59 & 0.002 & 3.16 \\
Pythium sp. BG01 & 1.80 & $\mathrm{NA}$ & 17.1 & $\mathrm{NA}$ \\
Plasmopara viticola & 1.72 & $\mathrm{NA}$ & traces & traces \\
Hyaloperonospora brassicae & 1.42 & traces & 0.75 & 0.39 \\
Hyaloperonospora parasitica & traces & 2.43 & 0.001 & 1.10 \\
Basidiophora entospora & traces & 1.34 & 1.07 & traces \\
Pythium catenulatum & $\mathrm{NA}$ & 0.32 & 0.23 & traces \\
Peronospora polygoni & 0.01 & traces & 0.49 & 2.95 \\
Peronospora variabilis & traces & traces & 0.40 & 0.83 \\
Peronospora sepium & traces & traces & 0.19 & traces \\
Pythium sp. 3862 & traces & traces & traces & 0.96 \\
Peronospora arthurii & traces & $\mathrm{NA}$ & traces & 0.29 \\
\hline
\end{tabular}

aUHR_E_AP = Ultra-high release ethanol and ultra-high release alpha-pinene.

$\mathrm{C}_{6} \mathrm{C}_{8}=$ Racemic 3-hydroxyhexan-2-one (K6), racemic 3-hydroxyoctan-2-one (K8), and ultra-high release ethanol.

General Longhorn = Ultra-high release ethanol, $(E)-6,10$-dimethyl-5,9-undecadien-2-ol (E-fuscumol), and

(E)-6,10-dimethyl-5,9-undecadien-2-yl (E-fuscumol acetate).

Pine Sawyer $=$ 2-undecyloxy-1-ethanol (monochamol), ultra-high release ethanol, ultra-high release alpha-pinene, and racemic 2-methyl-6-methylene-7-octen-4-ol (ipsenol).

bBelow $0.01 \%$ or not in the top 10 for this semiochemical.

cNot applicable or not in the top 10 for this semiochemical. 


\section{Discussion}

This study demonstrated that the described metagenomics approach to investigate insect trap fluids makes it possible to detect airborne, or insect-vectored fungal species even at very low abundances (i.e., $\leq 10$ OTU). A unique aspect of this study is that despite the fact that the CFIA has used insect traps in its national survey for many years, this is the first time that the formerly discarded trap preservation fluids have been analyzed, and the information extracted was highly valuable.

The project aimed to expand knowledge on phytopathogenic fungi and oomycetes by studying insect trap fluid samples, and this was assessed using the subtracted species datasets. More specifically, the project searched for interactions between phytopathogenic fungi and insects, and results, though ambiguous in certain cases, surely showed that there may be some novel insect-fungal relationships and effect of lure type that deserve further inquiry. Traditional methods such as cloning and culturing make it difficult for scientists to screen species at a larger scale but, our metagenomics approach now provides the opportunity to do so. Indeed, this project can provide a good overall assessment of the communities without having to isolate all organisms for identification purposes. This is a tool that regulatory agencies and other stakeholders could use for primary screening and disease monitoring. This approach is essentially a general detection survey for non-indigenous pathogens that partially fills a large gap that is a key step in the battle against invasive pathogens. By taking advantage of an established survey conducted by CFIA inspectors, other than shipment of fluid samples to the lab, no additional resources were required, thereby making this a cost-effective surveillance method. Just as air trap samplers are used to capture various pathogens in a given environment, our results suggested that insect traps can actively and passively gather worthy information from the environment.

Despite the fact that using ITS1 for fungal communities profiling does not always allow for resolution below the genus level for certain organisms [92], like it was presented in Supplementary Table S2, species subtraction filtered the data from background noise and highlighted numerous species with the potential to damage trees or other plants. Species detected in control traps were least likely to be vectored by insect andwere discarded, revealing several potentially phytopathogenic entities remaining that were more likely to be insect-transmitted. For instance, species unique to the various semiochemical types were from genera composed of important plant pathogens. Among others, Phoma glomerata, the causal agent of blight, leaf spots, and fruit rot of many plants, was uniquely detected in $\mathrm{C}_{6} \mathrm{C}_{8}$ samples, whereas Mycosphaerella areola (mildew) - despite the fact that it typically infects wheat leaves [93,94], field peas [95], and cruciferous vegetables [96] - was only detected in General Longhorn-baited trap samples. This semiochemical is an aggregation pheromone for longhorned beetles in the Spondylidinae [57] and Lamiinae subfamilies [70]. Similarly, the genera Mortierella and Phyllosticta (counting, P. minima: the causal agent of leaf spot in maple), which also contain numerous phytopathogenic species [97], were recovered from $\mathrm{C}_{6} \mathrm{C}_{8}$ semiochemical, which is an aggregation pheromone for longhorned beetles in the Cerambycinae subfamily.

Data collected from Pine Sawyer samples revealed fungi typically associated with insects such as Ceratocystidaceae, Ambrosiella spp., and Leptographium spp. [98-100]. Detection of Leptographium, a genus that includes the causal agent of blue stain in conifers, was not unexpected given its known association with bark beetles [99,101]. For example, L. piriforme is vectored by Tomicus piniperda (exotic), as well as other native bark beetles species [102]. Interestingly, the proportion of Leptographium species detected in the General Longhorn and Pine Sawyer semiochemical traps prior to species subtraction were greater than for $\mathrm{C}_{6} \mathrm{C}_{8}$ and UHR_E_AP. This could suggest an association with particular insect groups or demes. Because the phylogenetic analysis of Leptographium for species inference is usually done using a combination of at least three genic regions [103], more sequencing data, or alternate standardized assay (e.g., qPCR) would be required in order to validate down to the species level in this case (e.g., L. piriforme). 
Also, two considerable plant pathogen genera were observed solely within the Pine Sawyer lure subtracted data: Taphrina (specifically T. padii, the causal agent of cherry fruit deformation) and Phellinus ( $P$. ferrugineovelutinus is the causal agent of wood rot in alder and maple).

Given that some of the aforementioned fungal groups detected were less likely to actually encounter wood-boring insects, the presence of genera such as Phoma spp., Taphrina spp., and Mycosphaerella spp. could also be explained by the occurrence of other insects caught into the insect traps. In fact, flies, wasps, bees, dragonflies, moths, and other insects, which are regularly found by the CFIA inspectors in the traps (Troy Kimoto, personal communication), could have incidentally come in contact with infected plants prior to be captured, and, therefore, transport fungal propagules. For instance, honey bees are known vectors of bacteria, viruses, and fungus during foraging activities [104-108].

Likewise, some insects attracted to UHR_E_AP may be involved in the transmission of powdery mildews (Erysiphe spp.) and anthracnoses (Colletotrichum spp.) considering that these known pathogenic fungi were not detected in any other semiochemical treatment. However, because the addition of ethanol makes this lure attractive to a wide range of insects, there could be another reason for the detection of such pathogens in those samples, possibly being (i) the forest type or province of origin or weather conditions given that mildews are wind and water dispersed [109], or (ii) the capture of other insects including pollinators.

Similarly, the General Longhorn semiochemical (mainly attracts longhorned beetles and bark beetles) was associated with important phytopathogenic genera, including Pucciniastrum (among others, the rust P. circaeae), Sirococcus (specifically S. piceicola, and S. conigenus, two shoot blight causal agents), and Trametes (reduces wood value as a decaying agent) [97]. Additionally, while some Verticillium species are pathogenic to insects [110], other phytopathogenic Verticillium species are transported by jewel beetles (e.g. Agrilus spp.) and bark beetles [111]. For example, in Europe, V. dahliae is transported to Quercus spp. by the bark beetle Scolytus intricatus (does not occur in North America) and the ambrosia beetle Anisandrus dispar (F.) [111]. Therefore, the presence of $V$. isaacii (wilt in multiple plants) in samples baited with $\mathrm{C}_{6} \mathrm{C}_{8}$ may be due, in part, to ethanol contained in the lure because it is highly attractive to ambrosia beetles. However, not all Verticillium species can be resolved using the ITS1 region [112,113] so, the detection of $V$. isaacii using ITS1 was not conclusive at this point. Still, alignments of ITS1 sequences were done for the potential $V$. isaacii OTU with reference sequences (data not shown) and revealed a $100 \%$ match with $V$. isaacii, V. tricorpus, and V. klebahnii, which was expected. For the abovementioned reasons, complementary tests shall be performed to validate sensitive data.

There were similarities in communities between traps baited with UHR_E_AP and C6C8 (Tables 3, 4 and 6), and between the communities detected in Pine Sawyer and General Longhorn-baited samples. In contrast, differences occurred between the communities detected by the two former lure types versus the two latter. Such variation could be due to the fact that there were much fewer UHR_E_AP and $\mathrm{C}_{6} \mathrm{C}_{8}$ samples compared with the number of Pine Sawyer and General Longhorn samples, rendering comparison between the datasets unbalanced. The main reason for this difference is because the two former lures were used only during one season (2013), whereas the latter two were used for two collecting seasons (2014 and 2015). The forest type, the chemical composition, and the seasonal weather (temperature and rain) may also have influenced the communities retrieved.

Compared with fungi, the fewer number of identifiable oomycetes OTU in this study may be explained by the fact that the number of taxonomically described oomycetes is much lower [114-116]. One outstanding aspect of the oomycete analysis is that, following the species subtraction, most remaining species were unique to the General Longhorn samples (Supplementary Table S3) and none were recovered from the Pine Sawyer semiochemical. There were no Phytophthora species remaining after species subtraction but, Pythium (broad host range, mainly affecting roots or leaves) and Peronospora species (broad host range, mainly causing mildews) were dominant. Once again, this could contribute in demonstrating novel observations between plants, insects, and oomycetes. 
The ITS1 Phytophthora OTU (i.e., non-subtracted data) revealed Phytophthora foliorum (Rhododendron spp. and Azalea leaf blight [117,118]), Phytophthora sp. "kelmania" (affects gerbera [119] and Christmas trees [120]), and P. syringae (has wide host range causing numerous diseases [121]) but, because this intergenic spacer does not contain sufficient variation for species resolution, unlike ATP9-NAD9, those identifications were not conclusive. In contrast, the ATP9-NAD9 region allowed identification of P. cryptogea (numerous hosts causing different diseases [121]), P. foliorum, Phytophthora sp. "kelmania", and P. syringae but, these were discarded following species subtraction. This might indicate that Phytophthora-insects associations are not as frequent compared with other oomycetes such as Pythium spp.

Following species subtraction, there was a number of fungal species found that can degrade timber, some of which were associated with specific lures (Supplementary Table S2). Despite the fact that these fungi are not highly virulent, they can still damage or stain wood, thereby reducing timber marketability. The methodology used here appears to have the capacity to detect more harmful organisms if they had been present, because genera containing virulent pathogens were detected. The collection areas also seemed to have a role when profiling the fungal communities as OTU aggregated to geographic region (Supplementary Figure S4).

Considering that the spore trap samples reached the most sequences per sample compared with both the insect traps and the subtracted insect trap datasets, it refutes the possibility of having mistakenly discarded OTU due to spore trap undersampling. Because the control samples were highly diverse, it is more likely that the species remaining after subtraction are actually unique to the insect traps. There are logically fewer species in the subtracted data versus the original one, which is likely why those remaining had a rarefaction curve approaching saturation. Interestingly, the fact that only a part of the original insect data was sequenced deeply enough (i.e., rarefaction curve saturation) suggests that, for future NGS runs, sequencing fewer multiplexed fusion primer samples at a time would probably yield a more representative diversity analysis. In contrast, it appears that it was beyond sufficient for the spore traps, meaning more samples could be tested at once.

Given that numerous yeast are commonly associated with insects [122], the presence of Aureobasidium sp., Candida sp., Cladosporium sp., Cystobasidium sp., Cryptococcus sp., Hannaella sp., Kluyveromyces sp., Rhodotorula sp., Torulaspora sp., and Wickerhamomyces sp. in the unsubtracted dataset was expected (Table 4). Candida spp. are natural biocontrols agents of fruit and vegetable pests [122-124], and are also associated with bark beetles [21,23-25]. Following species subtraction, our results showed the presence of Candida michaelii only in the samples baited with the $\mathrm{C}_{6} \mathrm{C}_{8}$ semiochemical, which primarily attracts longhorned beetles, but the addition of ethanol makes it attractive to bark beetles as well.

Furthermore, the fact that the entomopathogenic species Colletotrichum nymphaeae was retrieved from the samples is promising for entomologists, because they could consider using our method to screen for either insect pathogens, or new biological pest controls. As a matter of fact, beneficial fungal endophytes have been studied for their ability to help plant's defenses [125]. For example, Beauveria bassiana infection has reduced populations of emerald ash borer (Agrilus planipennis) [126,127]. The gut-associated species detected (Candida michaelii [handsome fungus beetle]) demonstrated the robustness of our metagenomics approach in studying fungus-insect relationships regardless of the niche they occupy. Plus, this high-throughput method is more efficient compared with traditional assays because many sites could be sampled simultaneously due to the high volume of samples processed at a time, thus increasing the likelihood of detecting new nonnative fungal species.

Although some of the fungal genera or species that were detected in this project are already reported to be affiliated with insects, the results suggest that there may be other fungal and oomycetes species transported to potential host trees by insects. Based on the unique fungal and oomycete species detected within a given lure, our data suggests that there may be previously unrecorded associations between insects, fungi, and oomycetes. Each of the different semiochemicals employed in this study was attractive to a certain range of insect group or deme but, inevitably, passive or incidental collection of other insects 
(e.g., pollinators) contaminated by phytopathogens which they came across, though they would otherwise never transmit it to the plant host, occurred. The ethanol added also increased the chances of such event to happen.

All considered, making a direct link between the fungal species detected based on the semiochemical, the collection area, and the insects caught is very complex when solely using the presented approach. Nevertheless, if an organism of potential interest was detected, this method would provide stakeholders with location data that would narrow the target area for follow-up surveys. These targeted surveys would involve searching for symptomatic hosts, collecting samples, and performing validated low throughput assays. It is important to note that because the material studied consisted of airborne material rather than symptomatic trees, the detection of a given species does not automatically translate in the occurrence of diseased trees.

Despite the fact that this method may lack in providing forest stakeholders with a definitive answer, the observations shed light on new potential insect-pathogen associations. Yet, the approach to quickly screen species at a large geographic scale would be highly useful to (i) efficiently sample the environment for the presence of any new fungi or (ii) to obtain primary data in order to provide guidance to those who monitor and manage phytopathogens over large jurisdictions. Finally, future research could examine the fungal communities associated with specific wood-boring insects to determine if there are undiscovered relationships with these organisms and their host trees. 


\section{Supplementary Material S1: Semiochemicals' composition and additional details.}

Each lure set (i.e., C668, UHR_E_AP, General Longhorn, and Pine Sawyer) was placed on separate traps.

\section{First semiochemical set: $\mathrm{C}_{6} \mathrm{C}_{8}$.}

The first combination $\left(\mathrm{C}_{6} \mathrm{C}_{8}\right)$ consisted of racemic 3-hydroxyhexan-2-one $\left(\mathrm{C}_{6}\right)$ (Bedoukian Research Inc., Danbury, CT, USA), racemic 3-hydroxyoctan-2-one ( $\left.\mathrm{C}_{8}\right)$ (Bedoukian Research Inc.), and ultra-high release ethanol (UHR EtoH), where each chemical was placed within individual release devices. $\mathrm{C}_{6}$ and $\mathrm{C}_{8}$ were verified $99 \%$ pure by gas chromatography-mass spectrometry (GC-MS) by the Canadian Forest Service, and loaded into polyethylene pouches by Contech Inc (Delta, BC, Canada). Each pouch contained $1.4 \mathrm{~g}$ of either $\mathrm{C}_{6}$ or $\mathrm{C}_{8}$. The release rates (at $20^{\circ} \mathrm{C}$ ) were 20 $\mathrm{mg} / \mathrm{d}$ for $\mathrm{C}_{6}$, and $25 \mathrm{mg} / \mathrm{d}$ for $\mathrm{C}_{8}$. Two $\mathrm{C}_{6}$ and two $\mathrm{C}_{8}$ pouches (semiochemicals) were both placed on a trap to obtain cumulative release rates of 40 to $50 \mathrm{mg} / \mathrm{d}$.

\section{Second semiochemical set: UHR E AP.}

The second semiochemical set (UHR_E_AP) consisted of UHR EtoH and UHR alpha-pinene. The two chemicals were loaded into separate release devices and placed on an insect trap. The UHR ethanol (95\% purity, $121.5 \mathrm{~g}$ loaded/pouch) and UHR alpha-pinene [95\% (-) enantiomer, 172 g/pouch] lures (Contech Inc., Delta, BC, Canada) had release rates (at $20^{\circ} \mathrm{C}$ ) of $275 \mathrm{mg} / \mathrm{d}$ and $2 \mathrm{~g} / \mathrm{d}$, respectively. The UHR ethanol and UHR alpha-pinene chemicals were exactly the same throughout this project.

Third semiochemical set: General Longhorn.

The lure set consisted of UHR EtoH, (E)-6,10-dimethyl-5,9-undecadien-2-ol (E-fuscumol) and (E)-6,10-dimethyl-5,9-undecadien-2-yl (E-fuscumol acetate). Both $E$-fuscumol and $E$-fuscumol acetate were synthesized by Bedoukian Research Inc. and placed into polyethylene bubble caps by Contech Inc.; $130 \mathrm{mg} / \mathrm{bubble} \mathrm{cap}$ of $E$-fuscumol (release rate $=1 \mathrm{mg} / \mathrm{d}$ ), and $200 \mathrm{mg} / \mathrm{bubble} \mathrm{cap} \mathrm{of} E$-fuscumol acetate (release rate $=2 \mathrm{mg} / \mathrm{d}$ ).

Fourth semiochemical set: Pine Sawyer.

The Pine Sawyer lure set included four separate components consisting of 2-undecyloxy-1-ethanol (monochamol), UHR EtoH, UHR alpha-pinene and racemic 2-methyl-6-methylene-7-octen-4-ol (ipsenol). Monochamol (99.3\% purity, $0.025 \mathrm{~g} / \mathrm{bubble} \mathrm{cap}$ ) and racemic ipsenol (>99\% purity, $0.04 \mathrm{~g} / \mathrm{bubble} \mathrm{cap)} \mathrm{were} \mathrm{also} \mathrm{purchased} \mathrm{from} \mathrm{Contech} \mathrm{Inc.} \mathrm{and}$ had release rates $\left(20^{\circ} \mathrm{C}\right)$ of $0.2 \mathrm{mg} / \mathrm{d}$ and $0.4 \mathrm{mg} / \mathrm{d}$, respectively. 
Supplementary Table S1: Summary of the samples collected from 2013 to 2015.

\section{Semiochemical $^{\text {a }} \quad$ Number of samples $\quad$ Canadian provinces}

UHR_E_AP 39

\section{$\mathrm{C}_{6} \mathrm{C}_{8}$}

General Longhorn

Pine Sawyer

Total: 36

17

British Columbia, New Brunswick, Newfoundland and Labrador, Nova Scotia, Ontario, Prince Edward Island, and Quebec

16

aUHR_E_AP = Combination of two semiochemicals (ultra-high release (UHR) ethanol and UHR alpha-pinene) that attract a wide range of bark and wood-boring insects $[49,55,56]$.

$\mathrm{C}_{6} \mathrm{C}_{8}=$ Combination of three semiochemicals (racemic 3-hydroxyhexan-2-one, racemic 3-hydroxyoctan-2-one, and UHR ethanol). The first two chemicals are aggregation pheromones of some longhorned beetles in the Cerambycinae subfamily [54] but, the addition of UHR ethanol increases attraction to other wood-boring insects.

General Longhorn $=$ Combination of three semiochemicals (UHR ethanol, (E)-6,10-dimethyl-5,9-undecadien-2-ol (E-fuscumol), and (E)-6,10-dimethyl-5,9-undecadien-2-yl (E-fuscumol acetate)) used to attract Spondylidinae, Lamiinae, and Scolytinae beetles [57,58,70].

Pine Sawyer $=$ Combination of four semiochemicals (2-undecyloxy-1-ethanol (monochamol), UHR ethanol, UHR alpha-pinene, and racemic

2-methyl-6-methylene-7-octen-4-ol (ipsenol)) used to attract longhorned beetles (Monochamus) and bark and ambrosia beetles due to the added ethanol and alpha-pinene $[47,59,60]$. 


\section{2 of 43}

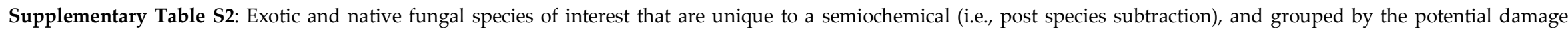
(= trophic status of concern) associated with those fungi. Also included is a risk level scale in terms of virulence. Identifications based on the ITS1 sequences obtained.

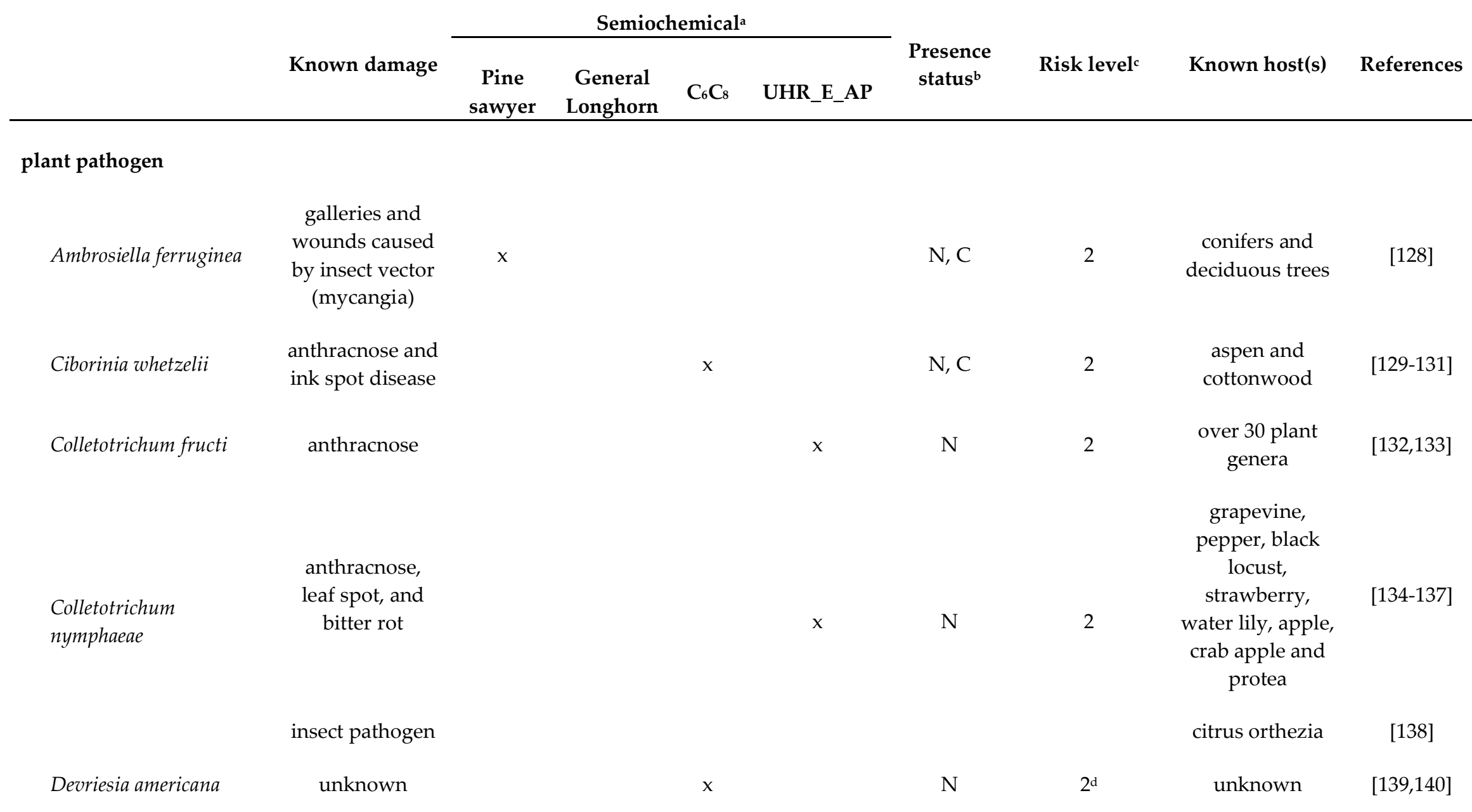




\begin{tabular}{|c|c|c|c|c|c|c|c|c|c|}
\hline Devriesia strelitziicola & death of leaves & & & & $x$ & E & 2 & Strelitzia spp. & [141-144] \\
\hline Erysiphe adunca & & $x$ & & & & $\mathrm{~N}, \mathrm{C}$ & 2 & $\begin{array}{l}\text { Populus spp. and } \\
\text { willow }\end{array}$ & {$[88,145]$} \\
\hline Erysiphe convolvuli & & & & & $x$ & $\mathrm{~N}, \mathrm{C}$ & 2 & $\begin{array}{l}\text { Calystegia spp. } \\
\text { and Convolvulus } \\
\text { spp. }\end{array}$ & [121] \\
\hline Erysiphe cruciferarum & & & & $\mathrm{x}$ & & $\mathrm{N}, \mathrm{C}$ & 2 & $\begin{array}{c}\text { mustard, } \\
\text { cabbage, bok } \\
\text { choy, and turnip }\end{array}$ & [146] \\
\hline Erysiphe diffusa & & & & & $x$ & $\mathrm{~N}$ & 2 & $\begin{array}{l}\text { soybean and } \\
\text { legumes }\end{array}$ & {$[147,148]$} \\
\hline Erysiphe elevata & $\begin{array}{l}\text { powdery } \\
\text { mildew }\end{array}$ & & $x$ & & & $\mathrm{~N}$ & 2 & flowering trees & {$[149,150]$} \\
\hline Golovinomyces depressus & & & $\mathrm{x}$ & & & E & 2 & $\begin{array}{l}\text { numerous } \\
\text { plants in the } \\
\text { Asteraceae } \\
\text { family }\end{array}$ & {$[88,121,145]$} \\
\hline Neoerysiphe galeopsidis & & & & & $x$ & $\mathrm{~N}, \mathrm{C}$ & 2 & $\begin{array}{l}\text { wild basil, } \\
\text { nettle, white } \\
\text { turtlehead, and } \\
\text { mint }\end{array}$ & $\begin{array}{c}{[129,146,15} \\
1,152]\end{array}$ \\
\hline Podosphaera clandestina & & & & $\mathrm{x}$ & & $\mathrm{N}, \mathrm{C}$ & 2 & $\begin{array}{c}\text { serviceberry, } \\
\text { hawthorn, } \\
\text { purple } \\
\text { loosestrife, crab }\end{array}$ & {$[97,129,151]$} \\
\hline
\end{tabular}


Podosphaera leucotricha

Podosphaera lini

Podosphaera negeri

Echinodontium

tinctorium

Leptographium sp.

Lirula macrospora

Meria laricis

Mollisia dextrinospora

Mycosphaerella areola

Phaeo-acremonium

inflatipes
4 of 43

apple, apricot, cherry, plum, peach and spirea $\mathrm{x}$

$$
\text { N, C }
$$

heart rot and brown stringy rot

blue stain and sapstain

x

needle cast

eyespot of cereal

areolate mildew

wilt and decline $\mathrm{x}$

$\mathrm{x}$

$\mathrm{x}$

$\mathrm{X}$

X
E

$x$

\begin{tabular}{|c|c|c|c|c|}
\hline & $\mathrm{E}$ & 2 & $\begin{array}{c}\text { flowering } \\
\text { shrubs }\end{array}$ & {$[145,154]$} \\
\hline & $\mathrm{N}, \mathrm{C}$ & 3 & $\begin{array}{c}\text { hemlock, fir, } \\
\text { and cedar }\end{array}$ & $\begin{array}{c}{[97,129,155} \\
156]\end{array}$ \\
\hline & $\mathrm{N}, \mathrm{C}$ & $1 ?$ & $\begin{array}{l}\text { conifer and } \\
\text { hardwood }\end{array}$ & [99-103,157] \\
\hline & $\mathrm{N}, \mathrm{C}$ & 3 & spruce & {$[129,158]$} \\
\hline & $\mathrm{N}, \mathrm{C}$ & 3 & larch & {$[97,159]$} \\
\hline $\mathrm{X}$ & $\mathrm{E}$ & 2 & cereals & [160-162] \\
\hline & $\mathrm{N}$ & 3 & cotton & {$[121,163]$} \\
\hline & $\mathrm{N}$ & $1 ?$ & $\begin{array}{c}\text { Quercus spp., } \\
\text { Nectandra spp., } \\
\text { whitebeam, } \\
\text { vine, and }\end{array}$ & $\begin{array}{c}{[18,121,164-} \\
166]\end{array}$ \\
\hline
\end{tabular}


blight, leaf

Phoma glomerata spots, and fruit rot

Pucciniastrum circaeae

rust

$x$

leaf spot and hard rot

Sirococcus conigenus

shoot blight

Sirococcus piceicola

Stagonospora

pseudopaludosa

Teratosphaeria

xenocryptica

Phyllosticta minima

Strelitziana mali

Taphrina padi

Verticillium isaacii

leaf spot

sooty blotch

\section{fruit}

deformation

vascular wilt
$\mathrm{N}, \mathrm{C}$

E

$\mathrm{x}$

\section{N, C}

N, C

N, C

$\mathrm{X}$ $\mathrm{x}$

x $\mathrm{x}$

E

$\mathrm{N}, \mathrm{C}$

E

E

$\mathrm{N}$ quince

over 80 different $\quad[121,129,16$

plants

7-169]

shrubs, fir and

2 Circaea spp.

$[121,170]$

flowers and corn $\quad[97,129,171]$

pine, spruce, fir, and hemlock

$[97,172,173]$

spruce

$[173,174]$

grass

[175]

2

eucalytpus

$[176,177]$

maple

$[88,97,129,1$

$78,179]$

3

apple and vine

[180-182]

2

cherry

[183-185]

2
[112,186] artichoke, tomato, spinach, 
insect gut associated

Candida michaelii

$\mathrm{N} / \mathrm{A}^{\mathrm{e}}$

$\mathrm{x}$

\section{loss of wood value}

Donkioporia albidofusca

$\mathrm{x}$

Melastiza chateri

Perenniporia luteola

Phlebiopsis sp.

Pleurotus ostreatus

white rot

Pluteus eludens

Pluteus phlebophorus

Ramaria pinicola

Steccherinum oreophilum

Trametes cubensis

$\mathrm{x}$

$x$
6 of 43

lettuce,

cauliflower,

eggplant,

pepper, and

strawberry

$\mathrm{x}$

$\mathrm{N}$

\section{N/A}

handsome

fungus beetle

[187]

$x$

$\mathrm{U}$

5

decaying wood

[88,188]

N, C

N, C
U

U

$\mathrm{X}$

$x$

N, C

U

5

5

U

5

decaying wood

decaying wood

[189]

decaying wood

[190,191]

decaying wood

$[97,129,131$ 151,192]

decaying wood

[88]

decaying wood

[88]

decaying wood

[88]

decaying wood

[129,193]

N

decaying wood

[88,194-196] 


\begin{tabular}{|c|c|c|c|c|c|c|c|}
\hline Antrodia albobrunnea & & $x$ & & $\mathrm{~N}, \mathrm{C}$ & 5 & decaying wood & {$[197,198]$} \\
\hline Sidera lunata & brown rot & & $\mathrm{x}$ & $\mathrm{E}$ & 5 & decaying wood & {$[88,199]$} \\
\hline Diatrype disciformis & beech barkspot & & $x$ & $\mathrm{~N}, \mathrm{C}$ & 3 & $\begin{array}{c}\text { decaying } \\
\text { hardwood trees }\end{array}$ & $\begin{array}{c}{[129,151,20} \\
0]\end{array}$ \\
\hline Hyphodontia microspora & & $x$ & & $\mathrm{E}$ & 5 & decaying wood & {$[201,202]$} \\
\hline $\begin{array}{l}\text { Phellinus } \\
\text { ferrugineovelutinus }\end{array}$ & other wood rots & $\mathrm{x}$ & & $\mathrm{N}, \mathrm{C}$ & 3 & maple and alder & {$[97,203,204]$} \\
\hline
\end{tabular}

aUHR_E_AP = Ultra-high release ethanol and ultra-high release alpha-pinene.

$\mathrm{C}_{6} \mathrm{C}_{8}=$ Racemic 3-hydroxyhexan-2-one (K6), racemic 3-hydroxyoctan-2-one (K8), and ultra-high release ethanol.

General Longhorn = Ultra-high release ethanol, (E)-6,10-dimethyl-5,9-undecadien-2-ol ( $E$-fuscumol), and (E)-6,10-dimethyl-5,9-undecadien-2-yl ( $E$-fuscumol acetate).

Pine Sawyer = 2-undecyloxy-1-ethanol (monochamol), ultra-high release ethanol, ultra-high release alpha-pinene, and racemic 2-methyl-6-methylene-7-octen-4-ol (ipsenol).

${ }^{b} \mathrm{~N}=$ the organism is native or reported to be present in North America, $\mathrm{C}=$ the organism is native or reported to be present in Canada, $\mathrm{E}=$ the organism is not reported or present in North America (exotic), and $\mathrm{U}=$ unknown status because information is lacking for Canada and North America.

cRisk associated with the organism on a 1 to 5 scale. $5=$ a riskless saprophyte fungus, $4=$ a saprophyte fungus capable of causing damages to plants $3=a$ weakly-virulent pathogenic fungus, $2=$ a moderate virulent pathogenic fungus but common in Canada, and $1=$ a highly-virulent pathogenic fungus.

dAssumption based on the impact of species within the same genus.

eNot applicable. 
Supplementary Table S3: Unique oomycete species detected in the different semiochemicals after proceeding with species subtraction and using the ITS1 genic region.

\section{Semiochemical $^{\mathrm{a}}$}

\section{General Longhorn}

Species

Peronospora farinosa

Peronospora sp. isolate 079405,59

Peronospora sp. UPS F-119986

Peronospora sparsa

Peronospora viciae

Pythium aff. hypogynum

Pythium sp. AvdB-2012

Pythium sp. BP2013k

Pythium sp. CAL-2011f

Pythium sp. P19300/1/3

\section{$\mathrm{C}_{6} \mathrm{C}_{8}$}

Pythium sp. CAL-2011e

Pythium sp. BG01

Pythium sp. P3862

No blast hit

\section{$\mathrm{C}_{6} \mathrm{C}_{8}$ and General Longhorn}

Saprolegnia sp. SAP1

Total: 11 1 3

a General Longhorn = Ultra-high release ethanol, $(E)-6,10$-dimethyl-5,9-undecadien-2-ol (E-fuscumol), and (E)-6,10-dimethyl-5,9-undecadien-2-yl (E-fuscumol acetate).

$\mathrm{C}_{6} \mathrm{C}_{8}=$ Racemic 3-hydroxyhexan-2-one (K6), racemic 3-hydroxyoctan-2-one (K8), and ultra-high release ethanol. 


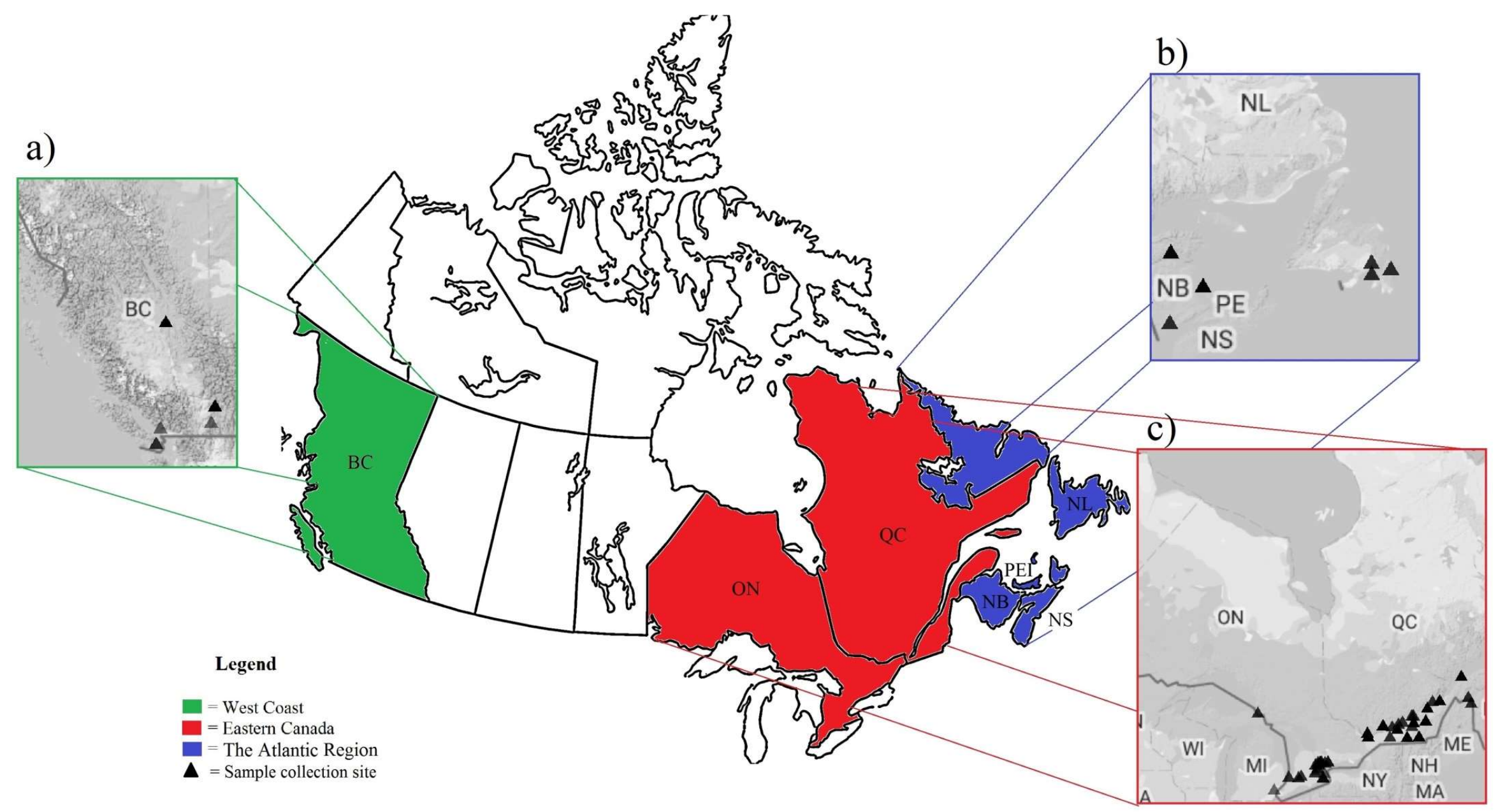

Supplementary Figure S1: Sampling sites in Canada; a) West Coast, b) the Atlantic Region, and c) Eastern Canada. Adapted from Google Earth. 
a)

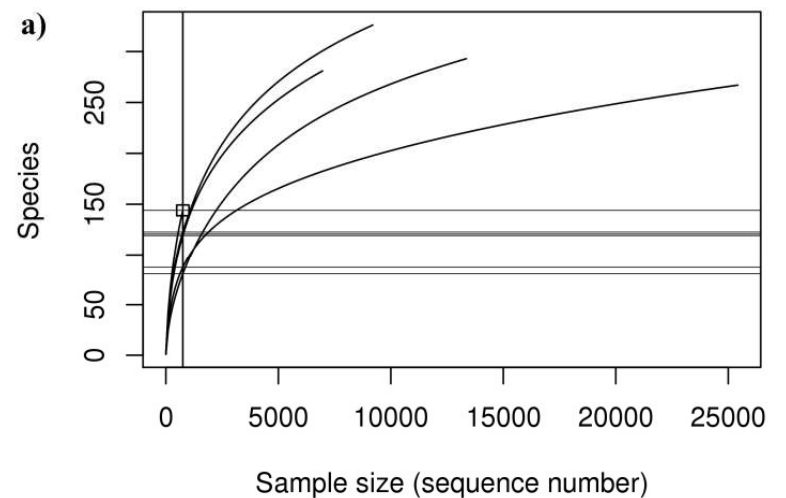

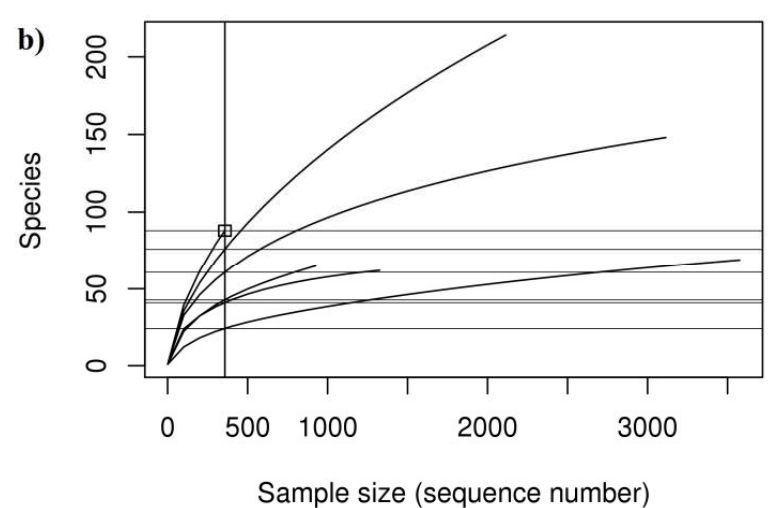

Supplementary Figure S2: Rarefaction curves (number of sequences obtained for each species) for a) spore trap samples and their respective b) insect trap samples (original data),

and c) insect trap samples (subtracted data) to visualize sequencing depth.






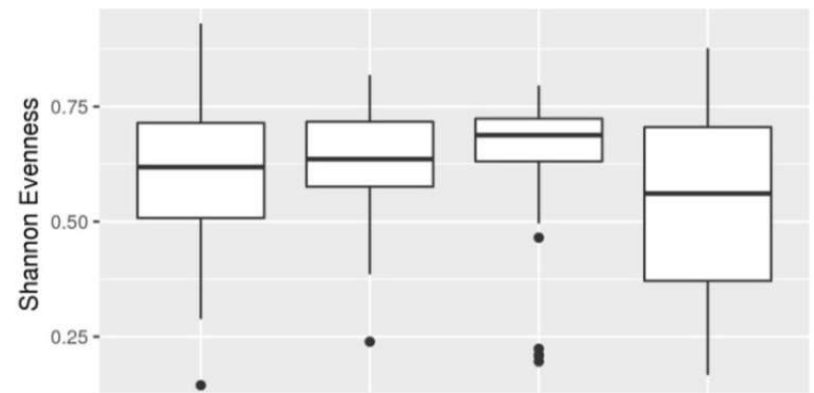

a)

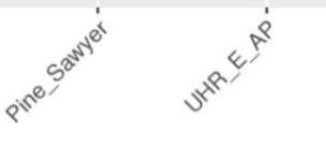

Lure

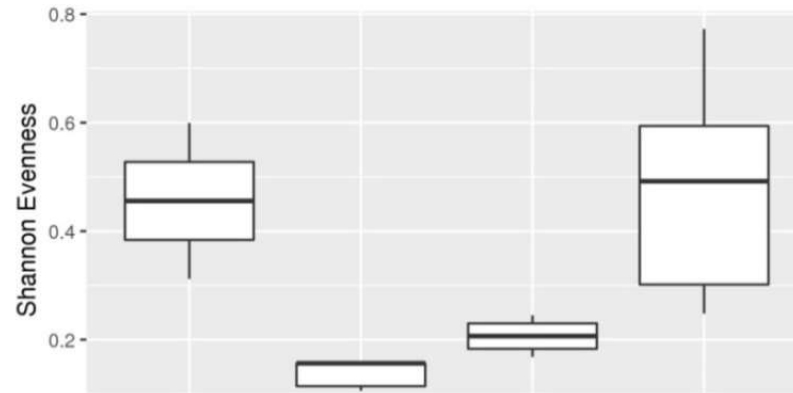

c)



Lure

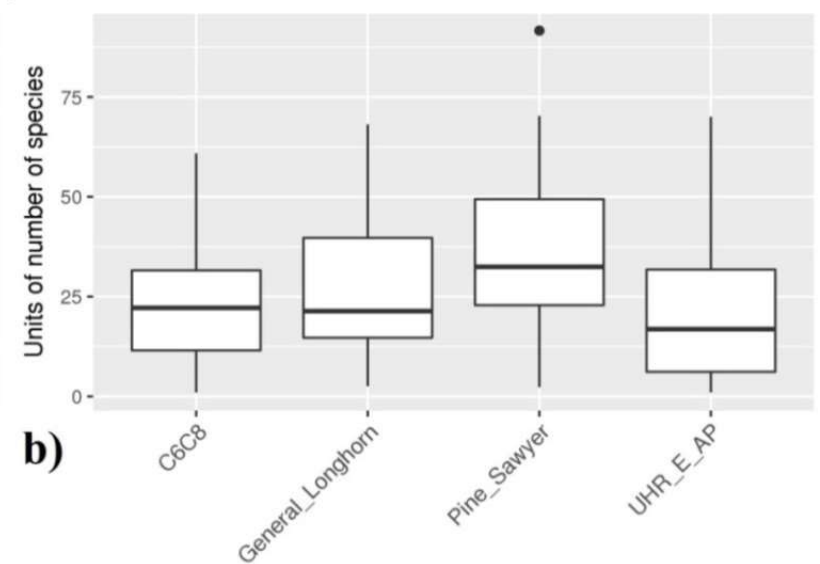

Lure

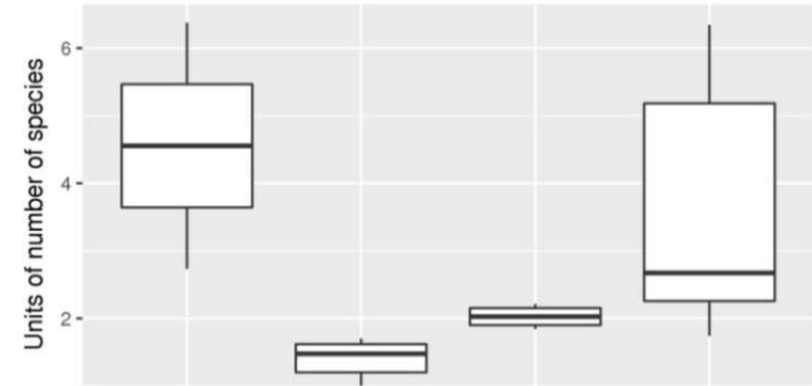

d)

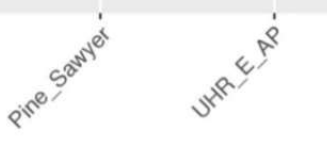

Lure

Supplementary Figure S3: fungal species a) evenness (Shannon) and b) true diversity (Shannon) by semiochemical type, and oomycete species c) evenness (Shannon) and d) true diversity (Shannon) by semiochemical type. The ITS1 sequences were used. 
a)



b)

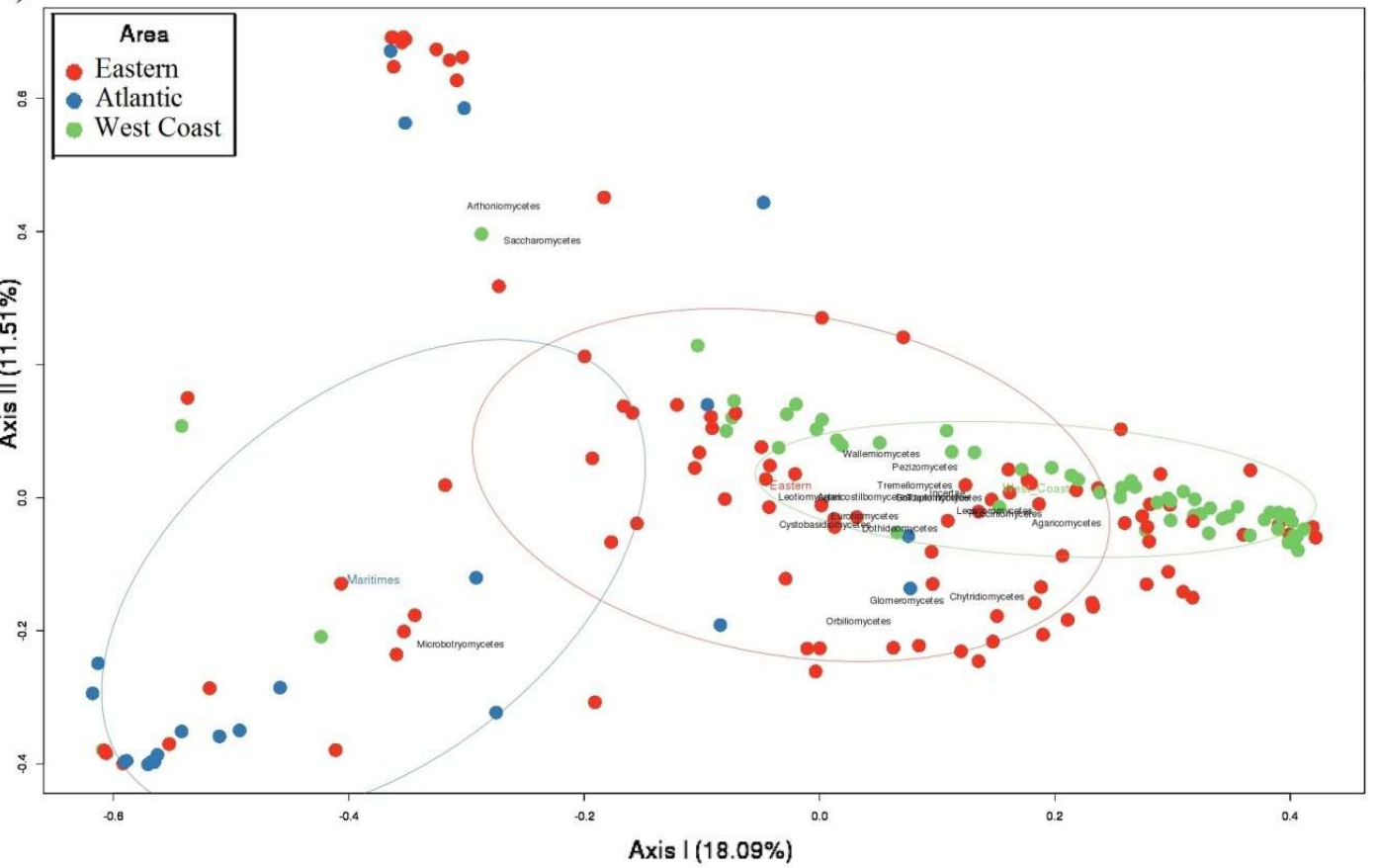

Supplementary Figure S4: Principal Coordinate Analysis of the fungal Operational Taxonomic Unit (ITS1) found in three Canadian geographic regions; the West Coast (BC), the Atlantic Region (PEI, NL, NS, and NB), and Eastern (QC and $\mathrm{ON})$ at the a) order and b) class taxonomic ranks. 
Author Contributions: Émilie D. Tremblay performed formal analysis, methodology development, visualization, programming, and data curation. Troy Kimoto drafted operational protocols for placement of insect traps in the field by inspection staff. Both É. D. Tremblay and T. Kimoto conducted investigation and wrote the original draft of this article. Dr. Guillaume Bilodeau conceptualized and supervised this study. Drs. Jean Bérubé and G. Bilodeau provided resources, and reviewed and edited the article.

Funding: This project was funded by the CFIA Research Partnership Strategy project OLF-P-1304, the Genomics Research and Development Initiative funding (QIS and CFIA OFL-P-1411), Genome Canada, and Genome BC through a Large Scale Applied Research Program (LSARP2112; Genome Canada grant) for the Tree Aggressors Identification using Genomic Approaches collaboration project (http://taigaforesthealth.com CFIA-RPS and CFIA-TD projects and GRDI-CFIA mandated).

Acknowledgments: The authors would like to thank Ron Neville, Lucie Gagné, Erin Bullas-Appleton, CFIA inspectors, and Dr. Richard Wilson who provided us with insect trap samples. Thank you to Miranda Newton and Hadil Sayed for their help with sample processing. Thank you to all of those who helped with the bioinformatics analysis, including: Dr. Ahmed Abdelfattah, Emily Giroux, Dr. Wen Chen, Dr. Marc-Olivier Duceppe, Iyaad Kandalaft, Dr. Guillaume Nicolas, Catherine Brown, Patrick Gagné, and Christine Lowe. Thanks to Drs. Louis Bernier and Claude Lemieux for their support and advices. Thanks to Dr. Bryan Brunet for sharing knowledge in entomology. Thank you to Drs. Marie-Claude Gagnon and Ian King for their advice and or helping editing this article.

Conflicts of Interest: The authors declare no conflict of interest. 
2 of 43

\section{References}

1. Hulme, P.E. Trade, transport and trouble: Managing invasive species pathways in an era of globalization. J. Appl. Ecol. 2009, 46, 10-18.

2. Haack, R.A. Intercepted scolytidae (coleoptera) at us ports of entry: 1985-2000. Int.Pest Manag. Rev. 2001, 6, 253-282.

3. Brockerhoff, E.G.; Bain, J.; Kimberley, M.; Knížek, M. Interception frequency of exotic bark and ambrosia beetles (coleoptera: Scolytinae) and relationship with establishment in new zealand and worldwide. Can. J. For. Res. 2006a, 36, 289-298.

4. Haack, R.A. Exotic bark-and wood-boring coleoptera in the united states: Recent establishments and interceptions. Can. J. For. Res. 2006, 36, 269-288.

5. Haack, R.A.; Hérard, F.; Sun, J.; Turgeon, J.J. Managing invasive populations of asian longhorned beetle and citrus longhorned beetle: A worldwide perspective. Annu. Rev. Entomol. 2010, 55, 521-546.

6. Gerson, H.; Illson-Skinner, B.; Turgeon, J. Live insects found in wood packaging materials after implementation of ispm 15. Government of canada poster, presented at the 2012 canadian forest service forest pest forum, ottawa, 2012. 2012.

7. Haack, R.A.; Britton, K.O.; Brockerhoff, E.G.; Cavey, J.F.; Garrett, L.J.; Kimberley, M.; Lowenstein, F.; Nuding, A.; Olson, L.J.; Turner, J. Effectiveness of the international phytosanitary standard ispm no. 15 on reducing wood borer infestation rates in wood packaging material entering the united states. PLOS ONE 2014, 9, e96611.

8. Hendrickson, O. Invasive alien species in canadian forests. In Alien invaders in canada's waters, wetlands, and forests., Claudi, R.; Nantel, P.; Muckle-Jeffs, E., Eds. Canadian Forest Service, Natural Resources Canada,: Ottawa, 2002; p 320.

9. Smith, G.; Hurley, J.; Sweeney, J.; Harrison, K.; MacKay, A. First north american record of the palearctic species tetropium fuscum (fabr.) (coleoptera: Cerambycidae). In Proceedings usda interagency research forum on gypsy moth and other invasive species, USDA Forest Service: Annapolis, MD, USA. Northeastern Research Station, Newtown Square, PA, USA. Gen. Tech. Rep. NE-300., 2002.

10. Ryan, K.; de Groot, P.; Smith, S.M. Evidence of interaction between sirex noctilio and other species inhabiting the bole of pinus. Agric. For. Entomol. 2012, 14, 187-195.

11. Herms, D.A.; McCullough, D.G. Emerald ash borer invasion of north america: History, biology, ecology, impacts, and management. Annu. Rev. Entomol. 2014, 59, 13-30.

12. Li, D.; Shi, J.; Lu, M.; Ren, L.; Zhen, C.; Luo, Y. Detection and identification of the invasive sirex noctilio (hymenoptera: Siricidae) fungal symbiont, amylostereum areolatum (russulales: Amylostereacea), in china and the stimulating effect of insect venom on laccase production by a. Areolatum yql03. J. Econ. Entomol. 2015, 108, 1136-1147.

13. Government of Canada. Mountain pine beetle; 2016.

14. Krokene, P.; Solheim, H. Pathogenicity of four blue-stain fungi associated with aggressive and nonaggressive bark beetles. Phytopathology 1998, 88, 39-44.

15. Levieux, J.; Lieutier, F.; Moser, J.C.; Perry, T.J. Transportation of phytopathogenic fungi by the bark beetle ips sexdentatus boerner and associated mites. J. Appl. Entomol. 1989, 108, 1-11.

16. Allen, E.; Humble, L. Nonindigenous species introductions: A threat to canada's forests and forest economy. Can. J. Plant Pathol. 2002, 24, 103-110. 
17. Negrón, J.F.; Witcosky, J.J.; Cain, R.J.; LaBonte, J.R.; Duerr, D.A.; McElwey, S.J.; Lee, J.C.; Seybold, S.J. The banded elm bark beetle: A new threat to the elms in north america. Am. Entomol. 2005, 51, 84-94.

18. Kubátová, A.; Kolařík, M.; Pažoutová, S. Phaeoacremonium rubrigenum-hyphomycete associated with bark beetles found in czechia. Folia Microbiol. 2004, 49, 99-104.

19. Epstein, L.; Sukhwinder, K.; VanderGheynst, J. Botryosphaeria-related dieback and control investigated in noncoastal california grapevines. Calif. Agric. 2008, 62, 161-166.

20. Moyo, P. The role of arthropods in the dispersal of trunk disease pathogens associated with petri disease and esca. Stellenbosch: Stellenbosch University, 2013.

21. Callaham, R.; Shifrine, M. The yeasts associated with bark beetles. Forest Sci. 1960, 6, 146-154.

22. Klimaszewski, J.; Morency, M.-J.; Labrie, P.; Seguin, A.; Langor, D.; Work, T.; Bourdon, C.; Thiffault, E.; Pare, D.; Newton, A.F. Molecular and microscopic analysis of the gut contents of abundant rove beetle species (coleoptera, staphylinidae) in the boreal balsam fir forest of quebec, canada. Zookeys 2013, 1.

23. Waalberg, M.E. Fungi associated with three common bark beetle species in norwegian scots pine forest. Norwegian University of Life Sciences, 2015.

24. Nguyen, N.H.; Suh, S.-O.; Erbil, C.K.; Blackwell, M. Metschnikowia noctiluminum sp. Nov., metschnikowia corniflorae sp. Nov., and candida chrysomelidarum sp. Nov., isolated from green lacewings and beetles. Mycol. Res. 2006, 110, 346-356.

25. Zhu, X.-f.; Zhang, D.-p.; Yang, S.; Zhang, Q.-w. Candida xinjiangensis sp. Nov., a new anamorphic yeast species isolated from scolytus scheryrewi semenov in china. Arch. Microbiol. 2017, 199, 377-383.

26. Mecteau, M.R.; Joseph, A.; Tweddell, R.J. Effect of organic and inorganic salts on the growth and development of fusarium sambucinum, a causal agent of potato dry rot. Mycol. Res. 2002, 106, 688-696.

27. Vettraino, A.M.; Roques, A.; Yart, A.; Fan, J.-T.; Sun, J.-H. Sentinel trees as a tool to forecast invasions of alien plant pathogens. PLoS 2015, 10.

28. Loo, J.A. Ecological impacts of non-indigenous invasive fungi as forest pathogens. Biol. Invasions 2009, 11, 81-96.

29. Bilodeau, G.J.; Martin, F.N.; Coffey, M.D.; Blomquist, C.L. Development of a multiplex assay for genus- and species-specific detection of phytophthora based on differences in mitochondrial gene order. Phytopathology 2014, 104, 733-748.

30. Hyder, N.; Coffey, M.D.; Stanghellini, M.E. Viability of oomycete propagules following ingestion and excretion by fungus gnats, shore flies, and snails. Plant Dis. 2009, 93, 720-726.

31. Webber, J.; Gibbs, J. Insect dissemination of fungal pathogens of trees. In: Relationships between bark beetles and symbiotic organisms. Academic Press: London, 1989.

32. Franco, F.P.; Moura, D.S.; Vivanco, J.M.; Silva-Filho, M.C. Plant-insect-pathogen interactions: A naturally complex ménage à trois. Curr. Opin. Microbiol. 2017, 37, 54-60.

33. Lazebnik, J.; Tibboel, M.; Dicke, M.; Loon, J.J. Inoculation of susceptible and resistant potato plants with the late blight pathogen phytophthora infestans: Effects on an aphid and its parasitoid. Entomol. Exp. Appl. 2017.

34. Ellsbury, M.; Pratt, R.; Knight, W. Effects of single and combined infection of arrowleaf clover with bean yellow mosaic virus and a phytophthora sp. On reproduction and colonization by pea aphids (homoptera: Aphididae). Environ. Entomol. 1985, 14, 356-359.

35. Pratt, R.; Ellsbury, M.; Barnett, O.; Knight, W. Interactions of bean yellow mosaic virus and an aphid vector with phytophthora root diseases in arrowleaf clover. Phytopathology 1982, 72, 1189-1192. 
4 of 43

36. Hulcr, J.; Dunn, R.R. The sudden emergence of pathogenicity in insect-fungus symbioses threatens naive forest ecosystems. Proc. R. Soc. Lond. B Biol. Sci. 2011, 278, 2866-2873.

37. Kanzaki, N.; Giblin-Davis, R.M. Vector-mediated transmission of plant pathogens: Chapter 7: Pine wilt and red ring, lethal plant diseases caused by insect-mediated bursaphelenchus nematodes. APS 2016.

38. Barroso, V.M.; Rocha, L.O.; Reis, T.A.; Reis, G.M.; Duarte, A.P.; Michelotto, M.D.; Correa, B. Fusarium verticillioides and fumonisin contamination in bt and non-bt maize cultivated in brazil. Mycotoxin Res. 2017, 33, 121-127.

39. Hell, K.; Cardwell, K.; Setamou, M.; Schulthess, F. Influence of insect infestation on aflatoxin contamination of stored maize in four agroecological regions in benin. Afr. Entomol. 2000, 8, 169-177.

40. Miller, S.S.; Reid, L.M.; Harris, L.J. Colonization of maize silks by fusarium graminearum, the causative organism of gibberella ear rot. Botany 2007, 85, 369-376.

41. Kirisits, T. Fungal associates of european bark beetles with special emphasis on the ophiostomatoid fungi. In Bark and wood boring insects in living trees in europe, a synthesis, Springer-Verlag Berlin Heidelberg: 2007; pp 181-236.

42. Adams, I.P.; Glover, R.H.; Monger, W.A.; Mumford, R.; Jackeviciene, E.; Navalinskiene, M.; Samuitiene, M.; Boonham, N. Next-generation sequencing and metagenomic analysis: A universal diagnostic tool in plant virology. Mol. Plant Pathol. 2009, 10, 537-545.

43. Tolin, S.A.; Langham, M.A.C.; ; G.R.C. Beetle transmission: A unique alliance of virus, vector, and host. In Vector-mediated transmission of plant pathogens, APS Press. American Phytopathological Society: 2016; pp 131-146.

44. Pinheiro, P.V.; Kliot, A.; Ghanim, M.; Cilia, M. Is there a role for symbiotic bacteria in plant virus transmission by insects? Curr. Opin. Insect Sci. 2015, 8, 69-78.

45. Hogenhout, S.A.; Oshima, K.; AMMAR, E.-D.; Kakizawa, S.; Kingdom, H.N.; Namba, S. Phytoplasmas: Bacteria that manipulate plants and insects. Mol. Plant Pathol. 2008, 9, 403-423.

46. Orlovskis, Z.; Canale, M.C.; Thole, V.; Pecher, P.; Lopes, J.R.; Hogenhout, S.A. Insect-borne plant pathogenic bacteria: Getting a ride goes beyond physical contact. Curr. Opin. Insect Sci. 2015, 9, 16-23.

47. Teale, S.A.; Wickham, J.D.; Zhang, F.; Su, J.; Chen, Y.; Xiao, W.; Hanks, L.M.; Millar, J.G. A male-produced aggregation pheromone of monochamus alternatus (coleoptera: Cerambycidae), a major vector of pine wood nematode. J. Econ. Entomol. 2011, 104, 1592-1598.

48. Roe, A.; Torson, A.; Bilodeau, G.B., P; Blackburn, G.; Cui, M.; Cusson, M.; Doucet, D.; Griess, V.; Lafond, V.; Paradis, G., et al. Biosurveillance of forest insects: Part i-integration and application of genomic tools to the surveillance of non-native forest insects. J. Pest Sci. 2018, 1-20.

49. Douglas, H.; Bouchard, P.; Anderson, R.S.; de Tonnancour, P.; Vigneault, R.; Webster, R.P. New curculionoidea (coleoptera) records for canada. Zookeys 2013, 13.

50. Bullas-Appleton, E.; Kimoto, T.; Turgeon, J.J. Discovery of trichoferus campestris (coleoptera: Cerambycidae) in ontario, canada and first host record in north america. Can. Entomol. 2014, 146, 111-116.

51. Government of Canada. Cfia deploys traps to detect emerald ash borer. 2010.

52. Government of Canada. Emerald ash borer - agrilus planipennis. 2015.

53. Gullan, P.C., PS. 4.3.3. Semiochemicals: Kairomones, allomones, and synomones. In The insects: An outline of entomology, Fifth Edition ed.; John Wiley \& Sons, Ltd: Canberra, Australia, 2014; Vol. 370. 
54. Ray, A.M.; Millar, J.G.; Moreira, J.A.; McElfresh, J.S.; Mitchell, R.F.; Barbour, J.D.; Hanks, L.M. North american species of cerambycid beetles in the genus neoclytus share a common hydroxyhexanone-hexanediol pheromone structural motif. J. Econ. Entomol. 2015.

55. Petrice, T.R.; Haack, R.A.; Poland, T.M. Evaluation of three trap types and five lures for monitoring hylurgus ligniperda (coleoptera: Scolytidae) and other local scolytids in new york. Great Lakes Entomol. 2018, 37, 1 .

56. Brockerhoff, E.G.; Jones, D.C.; Kimberley, M.O.; Suckling, D.M.; Donaldson, T. Nationwide survey for invasive wood-boring and bark beetles (coleoptera) using traps baited with pheromones and kairomones. Forest Ecol.Manag. 2006b, 228, 234-240.

57. Silk, P.J.; Sweeney, J.; Wu, J.; Price, J.; Gutowski, J.M.; Kettela, E.G. Evidence for a male-produced pheromone in tetropium fuscum (f.) and tetropium cinnamopterum (kirby)(coleoptera: Cerambycidae). Naturwissenschaften 2007, 94, 697.

58. Sweeney, J.D.; Silk, P.; Grebennikov, V.; Mandelshtam, M. Efficacy of semiochemical-baited traps for detection of scolytinae species (coleoptera: Curculionidae) in the russian far east. Eur. J. Entomol. 2016, $113,84$.

59. Pajares, J.A.; Álvarez, G.; Ibeas, F.; Gallego, D.; Hall, D.R.; Farman, D.I. Identification and field activity of a male-produced aggregation pheromone in the pine sawyer beetle, monochamus galloprovincialis. J. Chem. Ecol. 2010, 36, 570-583.

60. Ryall, K.; Silk, P.; Webster, R.P.; Gutowski, J.M.; Meng, Q.; Li, Y.; Gao, W.; Fidgen, J.; Kimoto, T.; Scarr, T. Further evidence that monochamol is attractive to monochamus (coleoptera: Cerambycidae) species, with attraction synergised by host plant volatiles and bark beetle (coleoptera: Curculionidae) pheromones. Can. Entomol 2015, 147, 564-579.

61. Tremblay, É.D.; Duceppe, M.-O.; Bérubé, J.A.; Kimoto, T.; Bilodeau, G.J. Screening for exotic forest pathogens to increase survey capacity using metagenomics. Phytopathology 2018 (in press).

62. Bérubé, J.A.; Nicolas, G.G. Alien fungal species on asymptomatic live woody plant material imported into canada. Can. J. Plant Pathol. 2015, 37, 67-81.

63. Aylward, J.; Steenkamp, E.T.; Dreyer, L.L.; Roets, F.; Wingfield, B.D.; Wingfield, M.J. A plant pathology perspective of fungal genome sequencing. IMA Fungus 2017, 8, 1-45.

64. Barba, M.; Czosnek, H.; Hadidi, A. Historical perspective, development and applications of next-generation sequencing in plant virology. Viruses 2014, 6, 106-136.

65. Wu, Q.; Ding, S.-W.; Zhang, Y.; Zhu, S. Identification of viruses and viroids by next-generation sequencing and homology-dependent and homology-independent algorithms. Annu. Rev. Phytopathol. 2015, 53, 425-444.

66. Barnes, C.; Szabo, L.; Johnson, J.; Nguyen, K.; Floyd, C.; Kurle, J. Detection of phakopsora pachyrhizi DNA in rain using qpcr and a portable rain collector. Phytopathology 2006, 96:S9.

67. Hambleton, S.; Tenuta, A.; Anderson, T.; Tropiano, R.; Bergeron, J.; Van Herk, C. Asian sbr monitoring program pays off in 2007 with first detections in canada - 2007 national sbr symposium. Amer. Phytopathol. Soc. 2007.

68. Szabo, L.J. Spore trapping: Technologies and results from 2007. In National Soybean Rust Symposium, The American Phytopathological Society: Louisville, KY, 2007.

69. Barnes, C.W.; Szabo, L.J.; Bowersox, V. Identifying and quantifying phakopsora pachyrhizi spores in rain. Phytopathology 2009, 99, 328-338. 
70. Mitchell, R.F.; Graham, E.E.; Wong, J.C.; Reagel, P.F.; Striman, B.L.; Hughes, G.P.; Paschen, M.A.; Ginzel, M.D.; Millar, J.G.; Hanks, L.M. Fuscumol and fuscumol acetate are general attractants for many species of cerambycid beetles in the subfamily lamiinae. Entomol. Exp. Appl. 2011, 141, 71-77.

71. Hayes, C.J.; DeGomez, T.E.; Clancy, K.M.; Williams, K.K.; McMillin, J.D.; Anhold, J.A. Evaluation of funnel traps for characterizing the bark beetle (coleoptera: Scolytidae) communities in ponderosa pine forests of north-central arizona. J. Econ. Entomol. 2008, 101, 1253-1265.

72. Government of British Columbia. Lindgren funnel traps. 2016.

73. Kox, L.F.F.; van Brouwershaven, I.R.; van de Vossenberg, B.; van den Beld, H.E.; Bonants, P.J.M.; de Gruyter, J. Diagnostic values and utility of immunological, morphological, and molecular methods for in planta detection of phytophthora ramorum. Phytopathology. 2007, 97, 1119-1129.

74. Miles, T.D.; Martin, F.N.; Robideau, G.; Bilodeau, G.; Coffey, M. Systematic development of phytophthora species-specific mitochondrial diagnostic markers for economically important members of the genus. Plant Dis. 2017, 101, 1162-1170.

75. Martin, F.N.; Abad, Z.G.; Balci, Y.; Ivors, K. Identification and detection of phytophthora: Reviewing our progress, identifying our needs. Plant Dis. 2012, 96, 1080-1103.

76. Edwards, D. Pcr purification: Ampure and simple. http://www.keatslab.org/blog/pcrpurificationampureandsimple (5 July 2017),

77. Thermofisher. Ion amplicon library preparation (fusion method), http://tools.Thermofisher.Com/content/sfs/manuals/4468326_ionampliconlibraryprep_fusionmethod ug.Pdf. (13 April 2017),

78. Breese, M.R.; Liu, Y. Ngsutils: A software suite for analyzing and manipulating next-generation sequencing datasets. Bioinformatics 2013, 29, 494-496.

79. Schloss, P.D.; Westcott, S.L.; Ryabin, T.; Hall, J.R.; Hartmann, M.; Hollister, E.B.; Lesniewski, R.A.; Oakley, B.B.; Parks, D.H.; Robinson, C.J. Introducing mothur: Open-source, platform-independent, community-supported software for describing and comparing microbial communities. Appl. Environ. Microbiol. 2009, 75, 7537-7541.

80. Bengtsson-Palme, J.; Ryberg, M.; Hartmann, M.; Branco, S.; Wang, Z.; Godhe, A.; Wit, P.; Sánchez-García, M.; Ebersberger, I.; Sousa, F. Improved software detection and extraction of its1 and its2 from ribosomal its sequences of fungi and other eukaryotes for analysis of environmental sequencing data. Methods Ecol. Evol. 2013, 4, 914-919.

81. Caporaso, J.G.; Kuczynski, J.; Stombaugh, J.; Bittinger, K.; Bushman, F.D.; Costello, E.K.; Fierer, N.; Pena, A.G.; Goodrich, J.K.; Gordon, J.I. Qiime allows analysis of high-throughput community sequencing data. Nat. Methods 2010, 7, 335-336.

82. Kõljalg, U.; Larsson, K.-H.; Abarenkov, K.; Nilsson, R.H.; Alexander, I.J.; Eberhardt, U.; Erland, S.; Høiland, K.; Kjøller, R.; Larsson, E., et al. Unite: A database providing web-based methods for the molecular identification of ectomycorrhizal fungi. New Phytol 2005, 166.

83. Kang, S. The phytophthora database project, http://www.Phytophthoradb.Org. (17 February 2016),

84. R Core Team. R: A language and environment for statistical computing. 2013.

85. Chen, W.; Simpson, J.; Levesque, C. Ram: $R$ for amplicon-sequencing-based microbial-ecology $r$ package version 1.2.1.3, http://cran.R-project.Org/package=ram, 2016.

86. Conway, J.R.; Lex, A.; Gehlenborg, N. Upsetr: An r package for the visualization of intersecting sets and their properties. B2J 2017, 120600.

87. Government of Canada. 2016-2017 plant protection survey report: Executive summary. 2017. 
88. Tedersoo, L.; Bahram, M.; Põlme, S.; Kõljalg, U.; Yorou, N.S.; Wijesundera, R.; Ruiz, L.V.; Vasco-Palacios, A.M.; Thu, P.Q.; Suija, A. Global diversity and geography of soil fungi. Science 2014, $346,1256688$.

89. Oksanen, J.; Blanchet, F.; Friendly, M.; Kindt, R.; Legendre, P.; McGlinn, D.; Minchin, P.; O'Hara, R.; Simpson, G.; Solymos, P., et al. Vegan: Community ecology package, 2018.

90. Jost, L. The new synthesis of diversity indices and similarity measures,. http://www.loujost.com/StatisticsandPhysics/DiversityandSimilarity/DiversitySimilarityHome.htm (9 January 2017),

91. Kéfi, $\quad$ S. $\quad$ Diversité. http://mon.univ-montp2.fr/claroline/backends/download.php?url=L0R5bmFtaXF1ZV9Db21tdW5hdX Rlc19FY29zeXN06G1lcy9FY29sb2dpZUNvbW11bmF1dGVzX29ubGluZS5wZGY\%3D\&cidReset=true \&cidReq=M2EFP (13 February 2017),

92. Raja, H.A.; Miller, A.N.; Pearce, C.J.; Oberlies, N.H. Fungal identification using molecular tools: A primer for the natural products research community. J. Nat. Prod. 2017, 80, 756-770.

93. Linde, C.; Zhan, J.; McDonald, B. Population structure of mycosphaerella graminicola: From lesions to continents. Phytopathology 2002, 92, 946-955.

94. Goodwin, S.B.; Kema, G.H. The genomes of mycosphaerella graminicola and m. Fijiensis. In Genomics of plant-associated fungi: Monocot pathogens, Springer-Verlag Berlin Heidelberg: 2014; pp 123-140.

95. Gossen, B.D.; Carisse, O.; Kawchuk, L.M.; Van Der Heyden, H.; McDonald, M.R. Recent changes in fungicide use and the fungicide insensitivity of plant pathogens in canada. Can. J. Plant Pathol. 2014, 36, 327-340.

96. Kennedy, R.; Wakeham, A.; Cullington, J. Production and immunodetection of ascospores of mycosphaerella brassicicola: Ringspot of vegetable crucifers. Plant Pathol. 1999, 48, 297-307.

97. Société de Protection des Plantes du Québec. Noms des maladies des plantes au canada. SPPQ: $2003 ;$ p 340.

98. French, J.R.; Roeper, R.A. Observations on trypodendron rufitarsis (coleoptera: Scolytidae) and its primary symbiotic fungus, ambrosiella ferruginea. Ann. Entomol. Soc. Am. 1972.

99. Jacobs, K.; Wingfield, M.J. Leptographium species: Tree pathogens, insect associates, and agents of blue-stain. American Phytopathological Society (APS Press): 2001.

100. Kim, S.; Harrington, T.C.; Lee, J.C.; Seybold, S.J. Leptographium tereforme sp. Nov. And other ophiostomatales isolated from the root-feeding bark beetle hylurgus ligniperda in california. Mycologia 2011, 103, 152-163.

101. Jacobs, K.; Bergdahl, D.R.; Wingfield, M.J.; Halik, S.; Seifert, K.A.; Bright, D.E.; Wingfield, B.D. Leptographium wingfieldii introduced into north america and found associated with exotic tomicus piniperda and native bark beetles. Mycol. Res. 2004, 108, 411-418.

102. Greif, M.D.; Gibas, C.F.C.; Currah, R.S. Leptographium piriforme sp. Nov., from a taxonomically diverse collection of arthropods collected in an aspen-dominated forest in western canada. Mycologia 2006, 98, 771-780.

103. Paciura, D.; De Beer, Z.; Jacobs, K.; Zhou, X.; Ye, H.; Wingfield, M.J. Eight new leptographium species associated with tree-infesting bark beetles in china. Persoonia 2010, 25, 94.

104. McArt, S.H.; Koch, H.; Irwin, R.E.; Adler, L.S. Arranging the bouquet of disease: Floral traits and the transmission of plant and animal pathogens. Ecology Letters 2014, 17, 624-636. 
105. Pattemore, D.; Goodwin, R.; McBrydie, H.; Hoyte, S.; Vanneste, J. Evidence of the role of honey bees (apis mellifera) as vectors of the bacterial plant pathogen pseudomonas syringae. Australas. Plant Path. 2014, 43, 571-575.

106. Johnson, K.; Stockwell, V.; Burgett, D.; Sugar, D.; Loper, J. Dispersal of erwinia amylovora and pseudomonas fluorescens by honey bees from hives to apple and pear blossoms. Phytopathology 1993, 83, 478-484.

107. Card, S.; Pearson, M.; Clover, G. Plant pathogens transmitted by pollen. Australas. Plant Path. 2007, 36, 455-461.

108. Stelfox, D.; Williams, J.; Soehngen, U.; Topping, R. Transport of sclerotinia sclerotiorum ascospores by rapeseed pollen in alberta. Plant Disease Reporter 1978, 62, 576-579.

109. Hau, B.; De Vallavieille-Pope, C. Chapter 15: Wind-dispersed diseases In The epidemiology of plant diseases, Second Edition ed.; Springer: Netherlands, 2006.

110. Bidochka, M.J.; Leger, R.J.S.; Stuart, A.; Gowanlock, K. Nuclear rdna phylogeny in the fungal genus verticillium and its relationship to insect and plant virulence, extracellular proteases and carbohydrases. Microbiology 1999, 145, 955-963.

111. Tiberi, R.; Panzavolta, T.; Bracalini, M.; Ragazzi, A.; Ginetti, B.; Moricca, S. Interactions between insects and fungal pathogens of forest and ornamental trees. Ital. J. Entomol. 2016, 45, 54-65.

112. Inderbitzin, P.; Bostock, R.M.; Davis, R.M.; Usami, T.; Platt, H.W.; Subbarao, K.V. Phylogenetics and taxonomy of the fungal vascular wilt pathogen verticillium, with the descriptions of five new species. PLOS ONE 2011, 6, e28341.

113. Inderbitzin, P.; Subbarao, K.V. Verticillium systematics and evolution: How confusion impedes verticillium wilt management and how to resolve it. Phytopathology 2014, 104, 564-574.

114. Hawksworth, D.L.; Rossman, A.Y. Where are all the undescribed fungi? Phytopathology 1997, 87, 888-891.

115. Rossman, A.; Palm, M. Why are phytophthora and other oomycota not true fungi?: Apsnet. The American Phytopathological Society: 2006.

116. Blackwell, M. The fungi: 1, 2, 3.. 5.1 million species? Am. J. Bot. 2011, 98, 426-438.

117. Donahoo, R.; Blomquist, C.L.; Thomas, S.L.; Moulton, J.K.; Cooke, D.E.; Lamour, K.H. Phytophthora foliorum sp. Nov., a new species causing leaf blight of azalea. Mycol. Res. 2006, 110, 1309-1322.

118. Government of Canada. Pest categorization phytophthora foliorum donahoo \& lamour leaf blight of azalea. Canadian Food Inspection Agency: 2015.

119. Rahman, M.Z.; Uematsu, S.; Suga, H.; Kageyama, K. Diversity of phytophthora species newly reported from japanese horticultural production. Mycoscience 2015, 56, 443-459.

120. McKeever, K.; Chastagner, G. A survey of phytophthora spp. Associated with abies in us christmas tree farms. Plant Dis. 2016, 100, 1161-1169.

121. Farr, D.F.; Rossman, A.Y. Fungal databases, u.S. National fungus collections, ars, usda. 2018.

122. Gonzalez, F. Symbiosis between yeasts and insects. Crop Prod. Sci. 2014, 3.

123. El-Ghaouth, A.; Wilson, C.L.; Wisniewski, M. Ultrastructural and cytochemical aspects of the biological control of botrytis cinerea by candida saitoana in apple fruit. Phytopathology 1998, 88, 282-291.

124. Droby, S.; Vinokur, V.; Weiss, B.; Cohen, L.; Daus, A.; Goldschmidt, E.; Porat, R. Induction of resistance to penicillium digitatum in grapefruit by the yeast biocontrol agent candida oleophila. Phytopathology 2002, 92, 393-399. 
125. Porras-Alfaro, A.; Bayman, P. Hidden fungi, emergent properties: Endophytes and microbiomes. Annu. Rev. Phytopathol. 2011, 49, 291-315.

126. Augustyniuk-Kram, A.; Kram, K.J. Entomopathogenic fungi as an important natural regulator of insect outbreaks in forests. In Forest ecosystems-more than just trees, InTech: 2012.

127. Liu, H.; Bauer, L.S. Microbial control of emerald ash borer, agrilus planipennis (coleoptera: Buprestidae) with beauveria bassiana strain gha: Greenhouse and field trials. Biol. Control 2008, 45, 124-132.

128. Alamouti, S.M.; Tsui, C.K.; Breuil, C. Multigene phylogeny of filamentous ambrosia fungi associated with ambrosia and bark beetles. Mycol. Res. 2009, 113, 822-835.

129. Ginns, J.H. Compendium of plant disease and decay fungi in canada, 1960-1980. Canadian Government Publishing Centre: 1986.

130. Holst-Jensen, A.; Vralstad, T.; Schumacher, T. Kohninia linnaeicola, a new genus and species of the sclerotiniaceae pathogenic to linnaea borealis. Mycologia 2004, 96, 135-142.

131. Callan, B.E. Diseases of populus in british columbia: A diagnostic manual. Canadian Forest Service: 1998.

132. Damm, U.; Woudenberg, J.; Cannon, P.; Crous, P. Colletotrichum species with curved conidia from herbaceous hosts. Fungal Divers. 2009, 39, 45.

133. Diao, Y.; Zhang, C.; Liu, F.; Wang, W.; Cai, L.; Liu, X. Colletotrichum species causing anthracnose disease of chili in china. Persoonia 2017, 38, 20-37.

134. Velho, A.; Stadnik, M.; Casanova, L.; Mondino, P.; Alaniz, S. First report of colletotrichum nymphaeae causing apple bitter rot in southern brazil. Plant Dis. 2014, 98, 567-567.

135. Liu, M.; Zhang, W.; Zhou, Y.; Liu, Y.; Yan, J.; Li, X.; Jayawardena, R.; Hyde, K. First report of twig anthracnose on grapevine caused by colletotrichum nymphaeae in china. Plant Dis. 2016, 100, 2530-2530.

136. Nasehi, A.; Kadir, J.; Rashid, T.; Awla, H.K.; Golkhandan, E.; Mahmodi, F. Occurrence of anthracnose fruit rot caused by colletotrichum nymphaeae on pepper (capsicum annuum) in malaysia. Plant Dis. 2016, 100, 1244-1244.

137. Yamagishi, N.; Sato, T.; Chuma, I.; Ishiyama, Y.; Tosa, Y. Anthracnose of black locust caused by colletotrichum nymphaeae (passerini) aa. J. Gen. Plant Pathol. 2016, 82, 174-176.

138. Mascarin, G.; Guarín-Molina, J.; Arthurs, S.; Humber, R.; de Andrade Moral, R.; Demétrio, C.; Júnior, I. Data on morphological features of mycosis induced by colletotrichum nymphaeae and lecanicillium longisporum on citrus orthezia scale. Data in Brief 2016, 8, 49-51.

139. Crous, P.; Braun, U.; Schubert, K.; Groenewald, J. Delimiting cladosporium from morphologically similar genera. Stud. Mycol. 2007, 58, 33-56.

140. Kim, Y.-H.; Kim, I.S.; Moon, E.Y.; Park, J.S.; Kim, S.-J.; Lim, J.-H.; Park, B.T.; Lee, E.J. High abundance and role of antifungal bacteria in compost-treated soils in a wildfire area. Microb. Ecol. 2011, 62, 725.

141. Crous, P.; Schoch, C.; Hyde, K.; Wood, A.; Gueidan, C.; De Hoog, G.; Groenewald, J. Phylogenetic lineages in the capnodiales. Stud. Mycol. 2009, 64, 17-47.

142. Schoch, C.L.; Spatafora, J.W.; Lumbsch, H.T.; Huhndorf, S.M.; Hyde, K.D.; Groenewald, J.Z.; Crous, P.W. A phylogenetic re-evaluation of dothideomycetes. CBS Fungal Biodiversity Centre: 2009.

143. Li, W.; Xiao, Y.; Wang, C.; Dang, J.; Chen, C.; Gao, L.; Batzer, J.C.; Sun, G.; Gleason, M.L. A new species of devriesia causing sooty blotch and flyspeck on rubber trees in china. Mycol. Prog. 2013, 12, 733-738.

144. Quaedvlieg, W.; Binder, M.; Groenewald, J.; Summerell, B.; Carnegie, A.; Burgess, T.; Crous, P. Introducing the consolidated species concept to resolve species in the teratosphaeriaceae. Persoonia 2014, 33, 1 . 
145. Braun, U.; Cook, R.T.A. Taxonomic manual of the erysiphales (powdery mildews). CBS Biodiversity Series 11 ed.; CBS-KNAW Fungal Biodiversity Centre: Utrecht, The Netherlands, 2012.

146. Amano, K. Host range and geographical distribution of the powdery mildew fungi. Japan Scientific Societies Press: 1986.

147. Fu, X.-Y.; Liu, S.-Y.; Jiang, W.-T.; Li, Y. Erysiphe diffusa: A newly recognized powdery mildew pathogen of wisteria sinensis. Plant Dis. 2015, 99, 1272-1272.

148. Baiswar, P.; Chandra, S.; Ngachan, S. Molecular evidence confirms presence of anamorph of erysiphe diffusa on soybean (glycine max) in northeast india. APDN 2016, 11, 25.

149. Vajna, L.; Fischl, G.; Kiss, L. Erysiphe elevata (syn. Microsphaera elevata), a new north american powdery mildew fungus in europe infecting catalpa bignonioides trees. Plant Pathol. 2004, 53, 244-244.

150. Denchev, C.M. New records of fungi, fungus-like organisms, and slime moulds from europe and asia: 1-6. Mycologia Balc. 2008, 93, 93-96.

151. Conners, I.L. An annotated index of plant diseases in canada and fungi recorded on plants in alaska, canada and greenland. Canadian Department of Agriculture, Ottawa: Ottawa, Canada, 1967; Vol. 1251.

152. Choi, I.; Kim, J.; Kim, K.; Cho, S.; Shin, H. First report of powdery mildew caused by neoerysiphe galeopsidis on stachys affinis in korea. Plant Dis. 2016, 100, 218.

153. Takamatsu, S.; Niinomi, S.; Harada, M.; Havrylenko, M. Molecular phylogenetic analyses reveal a close evolutionary relationship between podosphaera (erysiphales: Erysiphaceae) and its rosaceous hosts. Persoonia 2010, 24, 38.

154. Braun, U.; Delhey, R.; Dianese, J.; Hosagoudar, V. Miscellaneous notes on biotrophic micromycetes. Schlechtendalia 2006, 14, 85-97.

155. Maloy, O.C. A review of echinodontium tintorium ell. \& ev., the indian paint fungus. Bulletin of the Washington Agricultural Experiment Station 1967.

156. Etheridge, D.; Craig, H. Factors influencing infection and initiation of decay by the indian paint fungus (echinodontium tinctorium) in western hemlock. Can. J. For. Res. 1976, 6, 299-318.

157. Yin, M.; Duong, T.A.; Wingfield, M.J.; Zhou, X.; de Beer, Z.W. Taxonomy and phylogeny of the leptographium procerum complex, including leptographium sinense sp. Nov. And leptographium longiconidiophorum sp. Nov. Antonie van Leeuwenhoek 2015, 107, 547-563.

158. Müller, M.M.; Valjakka, R.; Suokko, A.; Hantula, J. Diversity of endophytic fungi of single norway spruce needles and their role as pioneer decomposers. Mol. Ecol. 2001, 10, 1801-1810.

159. Myren, D.T. Meria laricis found on european larch in ontario. Plant Dis. 1984, 68.

160. Crous, P.W.; Groenewald, J.E.; Gams, W. Eyespot of cereals revisited: Its phylogeny reveals new species relationships. Eur. J. Plant Pathol. 2003, 109, 841-850.

161. Johnston, P.; Park, D.; Manning, M. Neobulgaria alba sp. Nov. And its phialophora-like anamorph in native forests and kiwifruit orchards in new zealand. Mycotaxon 2010, 113, 385-396.

162. Kiyuna, T.; An, K.-D.; Kigawa, R.; Sano, C.; Sugiyama, J. Two new cladophialophora species, c. Tumbae sp. Nov. And c. Tumulicola sp. Nov., and chaetothyrialean fungi from biodeteriorated samples in the takamatsuzuka and kitora tumuli. Mycoscience 2018, 59, 75-84.

163. McGuire, J.U.; Crandall, B.S. Survey of insect pests and plant diseases of selected food crops of mexico, central america and panama. USDA Int. agric. Development Service: 1967.

164. Crous, P.W.; Gams, W.; Wingfield, M.J.; Van Wyk, P. Phaeoacremonium gen. Nov. Associated with wilt and decline diseases of woody hosts and human infections. Mycologia 1996, 786-796. 
165. Aroca, A.; Raposo, R.; Lunello, P. A biomarker for the identification of four phaeoacremonium species using the $\beta$-tubulin gene as the target sequence. Appl. Microbiol. Biotechnol. 2008, 80, 1131-1140.

166. Mohammadi, H.; Sharifi, S. Association of botryosphaeriaceae and phaeoacremonium species with insect-damaged quince shoots. J. Plant Pathol. 2016, 35-42.

167. Morgan-Jones, G. Phoma glomerata In Cmi descriptions of pathogenic fungi and bacteria, Commonwealth Mycological Institute: Kew, United Kingdom, 1967; Vol. no. 134.

168. Hosford, R. Phoma glomerata, a new pathogen of wheat and triticales. Phytopathology 1975, 65, 1236-1239.

169. Thomidis, T.; Michailides, T.J.; Exadaktylou, E. Phoma glomerata (corda) wollenw. \& hochapfel a new threat causing cankers on shoots of peach trees in greece. Eur. J. Plant Pathol. 2011, 131, 171.

170. Garibaldi, A.; Gilardi, G.; Ortu, G.; Gullino, M. First report of rust caused by pucciniastrum circaeae on fuchsia $\times$ hybrida in italy. Plant Dis. 2012, 96, 588-588.

171. French, A. California plant disease host index. California Dept. of Food and Agriculture, Division of Plant Industry: Sacramento, California, 1989.

172. Konrad, H.; Stauffer, C.; Kirisits, T.; Halmschlager, E. Phylogeographic variation among isolates of the sirococcus conigenus p group. Forest Pathol. 2007, 37, 22-39.

173. Rossman, A.; Castlebury, L.; Farr, D.; Stanosz, G. Sirococcus conigenus, sirococcus piceicola sp. Nov. And sirococcus tsugae sp. Nov. On conifers: Anamorphic fungi in the gnomoniaceae, diaporthales. Forest Pathol. 2008, 38, 47-60.

174. Walker, D.M.; Castlebury, L.A.; Rossman, A.Y.; Sogonov, M.V.; White, J.F. Systematics of genus gnomoniopsis (gnomoniaceae, diaporthales) based on a three gene phylogeny, host associations and morphology. Mycologia 2010, 102, 1479-1496.

175. Crous, P.; Wingfield, M.; Guarro, J.; Cheewangkoon, R.; Van der Bank, M.; Swart, W.; Stchigel, A.; Cano-Lira, J.; Roux, J.; Madrid, H. Fungal planet description sheets: 154-213. Persoonia 2013, 31, 188.

176. Crous, P.; Summerell, B.; Carnegie, A.; Wingfield, M.; Groenewald, J. Novel species of mycosphaerellaceae and teratosphaeriaceae. Persoonia 2009, 23, 119.

177. Hunter, G.C.; Crous, P.W.; Carnegie, A.J.; Burgess, T.I.; Wingfield, M.J. Mycosphaerella and teratosphaeria diseases of eucalyptus; easily confused and with serious consequences. Fungal Divers. 2011, 50, 145.

178. Bissett, J.; Darbyshire, S.J. Phyllosticta hamamelidis. Fungi Canadenses 1984, 276.

179. Mcelrone, A.J.; Reid, C.D.; Hoye, K.A.; Hart, E.; Jackson, R.B. Elevated co2 reduces disease incidence and severity of a red maple fungal pathogen via changes in host physiology and leaf chemistry. Glob. Change Biol. 2005, 11, 1828-1836.

180. Zhang, R.; Yang, H.; Sun, G.; Li, H.; Zhuang, J.; Zhai, X.; Gleason, M.L. Strelitziana mali, a new species causing sooty blotch on apple fruit. Mycotaxon 2009, 110, 477-485.

181. Gleason, M.L.; Batzer, J.C.; Sun, G.; Zhang, R.; Arias, M.M.D.; Sutton, T.B.; Crous, P.W.; Ivanović, M.; McManus, P.S.; Cooley, D.R. A new view of sooty blotch and flyspeck. Plant Dis. 2011, 95, 368-383.

182. Crous, P.; Shivas, R.; Wingfield, M.; Summerell, B.; Rossman, A.; Alves, J.; Adams, G.; Barreto, R.; Bell, A.; Coutinho, M., et al. Fungal planet description sheets: 128-153. Persoonia 2012, 29, 146-201.

183. Mix, A.J. Monograph of the genus taphrina. University Of Kansas; London: 1949; Vol. 33.

184. Mułenko, W.; Majewski, T.; Ruszkiewicz-Michalska, M. A preliminary checklist of micromycetes in poland. W. Szafer Institute of Botany, Polish Academy of Sciences: 2008.

185. Eriksson, O.E. Checklist of the non-lichenized ascomycetes of sweden. Acta Universitatis Upsaliensis: 2014. 
186. Gurung, S.; Short, D.P.; Hu, X.; Sandoya, G.V.; Hayes, R.J.; Koike, S.T.; Subbarao, K.V. Host range of verticillium isaacii and verticillium klebahnii from artichoke, spinach, and lettuce. Plant Dis. 2015, 99, 933-938.

187. Suh, S.-O.; Nguyen, N.H.; Blackwell, M. Nine new candida species near c. Membranifaciens isolated from insects. Mycol. Res. 2005, 109, 1045-1056.

188. Vlasák, J.; Kout, J.; Dvořák, D. Taxonomical position of polypore dichomitus albidofuscus: Donkioporia albidofusca comb. Nov. Mycol. Prog. 2010, 9, 147-150.

189. Zhao, C.-L.; Cui, B.-K. Three new perenniporia (polyporales, basidiomycota) species from china based on morphological and molecular data. Mycoscience 2013, 54, 231-240.

190. Agustini, L.; Wahyuno, D.; Indrayadi, H.; Glen, M. In vitro interaction between phlebiopsis sp. And ganoderma philippii isolates. Forest Pathol. 2014, 44, 472-476.

191. Government of Canada. Phlebiopsis gigantea strain vra 1992. Health Canada Pest Management Regulatory Agency: Ottawa, Ontario, Canada 2014.

192. Bezalel, L.; Hadar, Y.; Cerniglia, C.E. Mineralization of polycyclic aromatic hydrocarbons by the white rot fungus pleurotus ostreatus. Appl. Environ. Microbiol. 1996, 62, 292-295.

193. Farr, D.F.; Rossman, A.Y. Fungal databases, u.S. National fungus collections, ars, usda. 1989.

194. Overholts, L.O. The polyporaceae of the united states, alaska, and canada. The University of Michigan Press: 1953.

195. United States Department of Agriculture. Index of plant diseases in the united states. United States Department of Agriculture: 1960.

196. Justo, A.; Hibbett, D.S. Phylogenetic classification of trametes (basidiomycota, polyporales) based on a five-marker dataset. Taxon 2011, 60, 1567-1583.

197. Volk, T.J.; Burdsall, H.; Reynolds, K. Checklist and host index of wood-inhabiting fungi of alaska. Mycotaxon 1994, 52, 1-46.

198. Karasiński, D.; Niemelä, T. Anthoporia, a new genus in the polyporales (agaricomycetes). Polish Bot. J. 2016, 61, 7-14.

199. Miettinen, O.; Larsson, K.-H. Sidera, a new genus in hymenochaetales with poroid and hydnoid species. Mycol. Prog. 2011, 10, 131-141.

200. Blackwell, M.; Jones, K. Taxonomic diversity and interactions of insect-associated ascomycetes. Biodivers. Conserv. 1997, 6, 689-699.

201. Gilbertson, R.L.; Bigelow, D.M.; Hemmes, D.E.; Desjardin, D.E. Annotated check list of wood-rotting basidiomycetes of hawai'i. Mycotaxon 2002, 82, 215-239.

202. Unterseher, M.; Otto, P.; Morawetz, W. Species richness and substrate specificity of lignicolous fungi in the canopy of a temperate, mixed deciduous forest. Mycol. Prog. 2005, 4, 117-132.

203. Hanlin, R.T. Host index to the basidiomycetes of georgia. Georgia Experiment Station: 1966.

204. Minter, D.W.; Hernández, M.R.; Portales, J.M. Fungi of the caribbean: An annotated checklist. PMDS Publishing: 2001. 